S

\title{
Facility Effluent Monitoring Plan for the Waste Receiving and Processing Facility (WRAP)
}

Prepared for the U.S. Department of Energy Assistant Secretary for Environmental Management

Project Hanford Management Contractor for the

U.S. Department of Energy under Contract DE-AC06-96RL13200

Fluor Hanford

P.O. Box 1000

Richland, Washington 


\section{Facility Effluent Monitoring Plan for the Waste Receiving and Processing Facility (WRAP)}

Prepared for the U.S. Department of Energy

Assistant Secretary for Environmental Management

\section{Fluor Hanford}

P.O. Box 1000

Richland, Washington

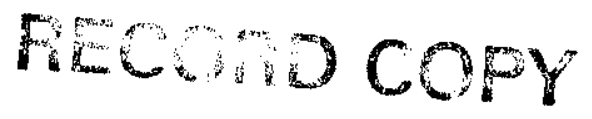




\section{RELEASE AUTHORIZATION}

Document HNF-EP-0885, Revision 1

Number:

Document Title: Facility Effluent Monitoring Plan for the Waste Receiving and

Processing Facility (WRAP)

\section{This document, reviewed in accordance with DOE Order 241.1, "Scientific and Technical Information Management," and DOE G 241.1-1, "Guide to the Management of Scientific and Technical Information," does not contain classified or sensitive unclassified information and is:}

\section{APPROVED FOR PUBLIC RELEASE}

\begin{tabular}{|c|c|}
\hline 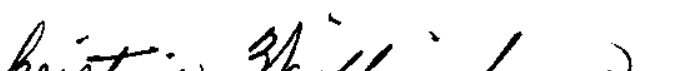 & $3 / 8 / 2000$ \\
\hline Christine Willingham & Clearance Date \\
\hline $\begin{array}{l}\text { Lockheed Martin Services, Inc. } \\
\text { Document Control//nformation Clearance }\end{array}$ & \\
\hline
\end{tabular}

Reviowed for Appled Technobgy, Business Sensitive, Classified, Copynighted, Export Controled, Patent, PersonelPrivate, Proprietary, Protected CRADA, Trademark, Unclessified Controlod Nucler Information.

Trademerk Discleimer. Reference herein to eny specific commercial product, process, or senvice by trade name, trademerk, manufacturer, or otherwise, does not necessarily constitute or imply its endorsement, recommendation, or favoring by the United States Government or eny agency thereof or its contractors or subcontractors. The views and opinions of euthors expressed herein do not necessenily state or reflect those of the United Stotes Government or any egency thereof. This report has been reproduced from the Dest ivaleble copy.

Printed in the United Stotes of America.

Available to the U.S. Depertment of Energy end its contrectors from the U.S. Depertment of Energy Office of Scientific and Technical Information, P.O. Box 62, Osk Ridge, TN 37831; Telaphone: 423/576-8401.

Avaibble to the pubic from the U.S. Depertment of Commerce Netional Techrical Informetion Service, 5285 Port Royal Roed, Springfield, VA 22161; Telaphone: 703/487-4650. 
HNF-EP-0885-1

\section{APPROVAL}

Document Title: Facility Effluent Monitoring Plan for the Waste Receiving and Processing Facility (WRAP)

Prepared By:

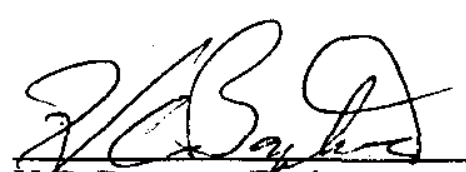

H.C. Boynton, Bnvironmental Compliance Officer

WRAP Environmental Compliance

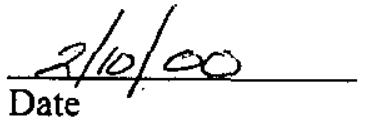

$2 / 25 / 00$ WRAP Facility

Approved By:

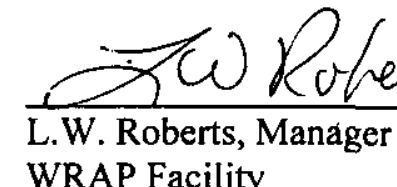

\section{$\frac{1}{5}$}

Approved By:

Approved By:

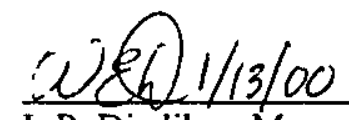

L.P. Diediker, Manager Monitoring and Reporting

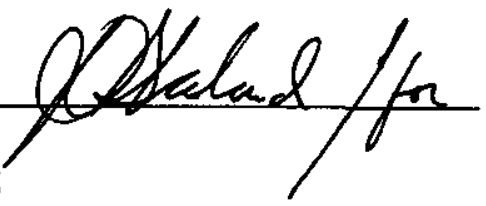

$\frac{1 / 13 / 00}{\text { Date }}$

$0 z-14-00$

W.R. Thackaberry, Equineer

Quality Assurance 
HNF-EP-0885-1

This page intentionally left blank. 
HNF-EP-0885-1

\title{
FACILITY EFFLUENT MONITORING PLAN FOR THE WASTE RECEIVING AND PROCESSING FACILITY
}

\begin{abstract}
A facility effluent monitoring plan is required by the U.S. Department of Energy in Order $5400.1^{\prime}$ for any operations that involve hazardous materials and radioactive substances that could impact employee public safety, or the environment. This facility effluent monitoring plan assesses effluent monitoring systems and evaluates whether these system are adequate to ensure the public health and safety as specified in applicable federal, state, and local requirements.
\end{abstract}

This facility effluent monitoring plan ensures long-range integrity of the effluent monitoring systems by requiring an update whenever a new process or operation introduces new hazardous materials or significant radioactive materials. This document must be reviewed annually even if there are no operational changes, and must be updated, as a minimum, every 3 years.

\footnotetext{
' General Environmental Protection Program, DOE Order 5400.1, U.S. Department of Energy, Washington, D.C.
} 
HNF-EP-0885-1

This page intentionally left blank. 


\title{
CONTENTS
}

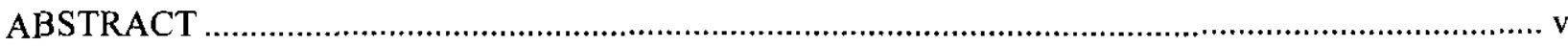

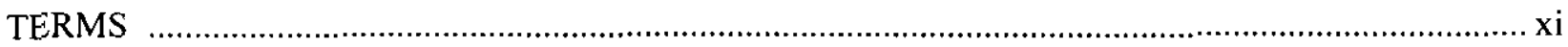

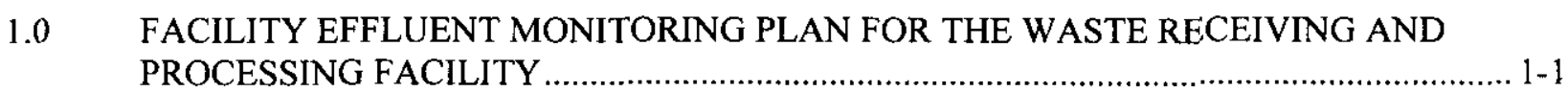

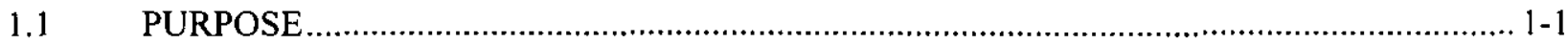

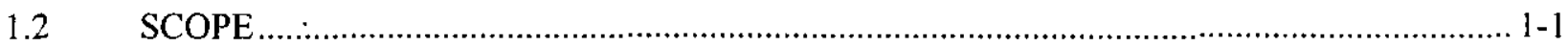

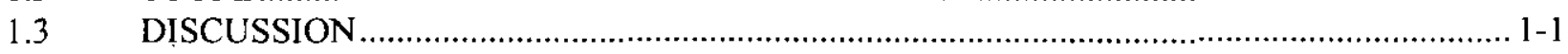

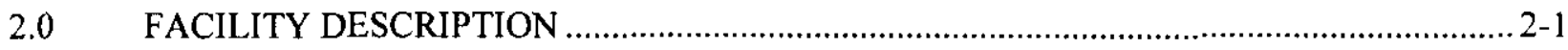

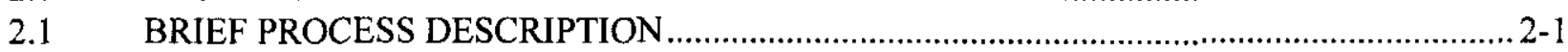

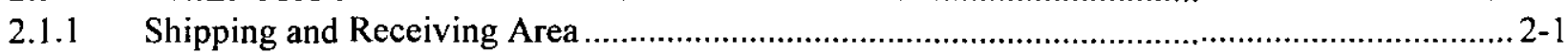

2.1.2 Nondestructive Examination and Nondestructive Assay Area .......................................... 2-2

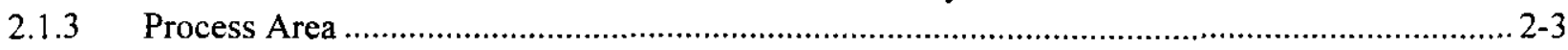

2.1.4 Sample Management Area ..................................................................................... 2-4

2.2 IDENTIFICATION AND CHARACTERIZATION OF POTENTIAL SOURCE TERMS ..... 2-4

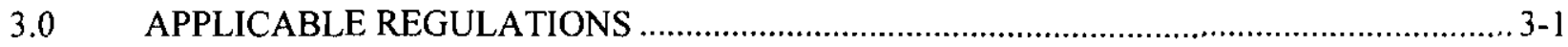

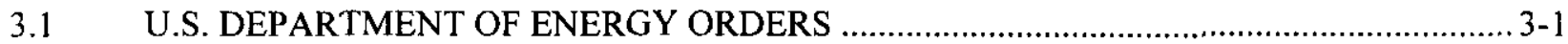

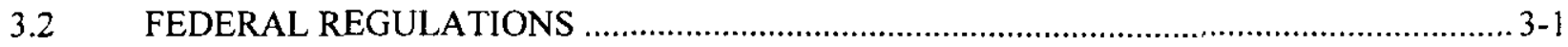

3.2.1 National Emission Standards for Hazardous Air Pollutants (40 CFR 61, Subpart H).............. 3-1

3.2.2 State Operating Permit Program (40 CFR 70) ............................................................... 3-2

3.2.3 Identification and Listing of Hazardous Waste (40 CFR 261) .......................................... 3-2

3.2.4 Designation, Reportable Quantities, and Notification (40 CFR 302) .................................... 3-2

3.3 INDUSTRY STANDARDS UNDER AMERICAN NATIONAL STANDARDS INSTITUTE ............................................................................................................ $3-2$

3.3.1 Guide to Sampling Airborne Radioactive Materials in Nuclear Facilities (ANSI N13.1)........ 3-3

3.3.2 Specification and Performance of Onsite Instrumentation for Continuously Monitoring Radioactivity in Effluents (ANSI N42.18) ...................................................................... 3-3

3.4 WASHINGTON STATE REGULATIONS ............................................................. 3-3

3.4.1 Air Operating Permit Program (WAC 173-401) ............................................................. 3-3

3.4.2 Ambient Air Quality Standards and Emission Limits for Radionuclides (WAC 173-480) ....... 3-3

3.4.3 Radiation Protection - Air Emissions (WAC 246-247) ..................................................... 3-4

3.4.4 Water Quality Standards for Groundwater (WAC 173-200) .............................................. 3-4

3.4.5 State Waste Discharge Permit Program (WAC 173-216) ....................................................... 3-4

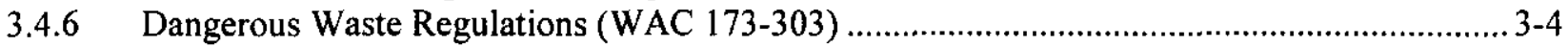

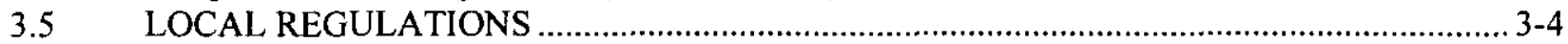

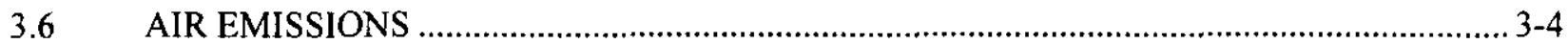

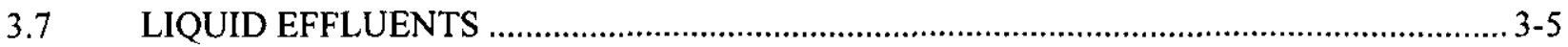

4.0 IDENTIFICATION AND CHARACTERIZATION OF EFFLUENT STREAMS .................. 4-1

4.1 IDENTIFICATION AND CHARACTERIZATION OF SOURCE TERMS
CONTRIBUTING TO EACH EFFLUENT STREAM $\ldots \ldots \ldots \ldots \ldots \ldots \ldots \ldots \ldots \ldots \ldots \ldots \ldots \ldots \ldots \ldots \ldots \ldots \ldots \ldots \ldots \ldots \ldots \ldots \ldots \ldots \ldots \ldots \ldots \ldots$

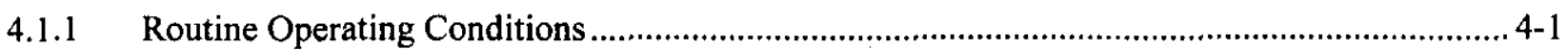

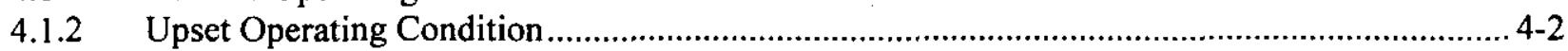




\section{CONTENTS (cont)}

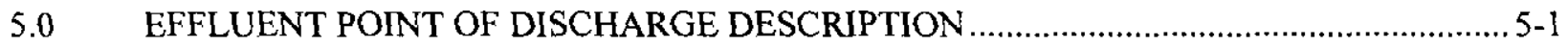

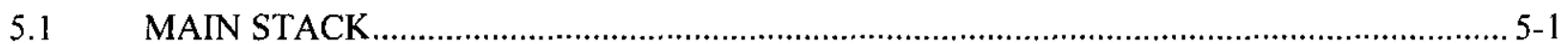

LIQUID EFFLUENT DISCHARGE LOCATION …...................................................... 5-1

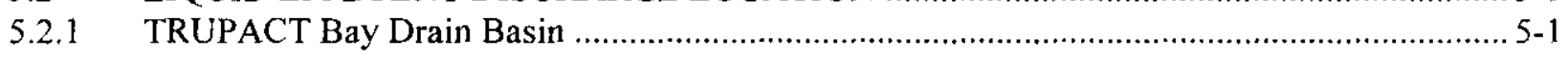

5.2.2 Compressor Condensate Drain Basin .......................................................................... 5-2

6.0 EFFLUENT MONITORING/SAMPLING SYSTEM DESIGN CRITERIA ........................ 6-1

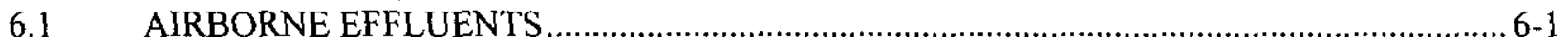

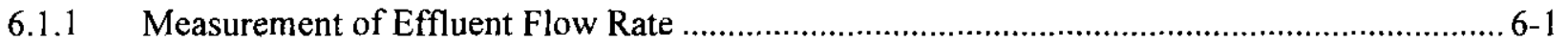

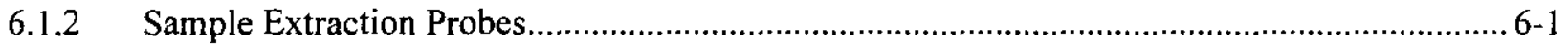

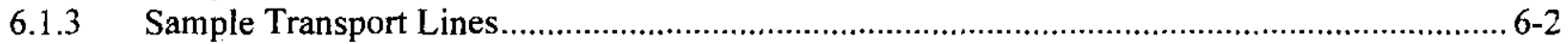

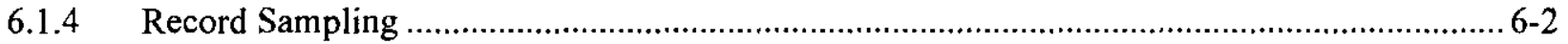

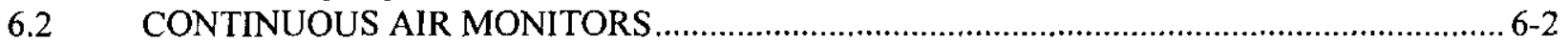

7.0 CHARACTERIZATION OF CURRENT EFFLUENT MONITORING SYSTEM ................ 7-1

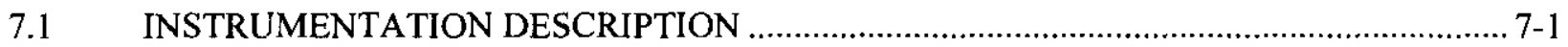

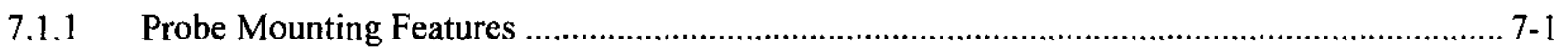

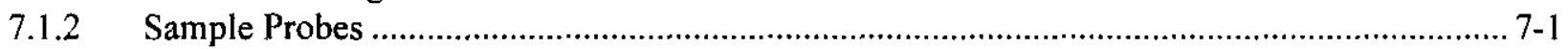

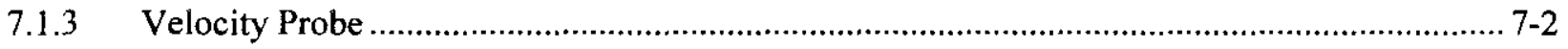

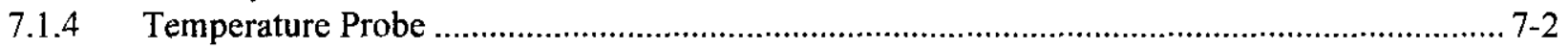

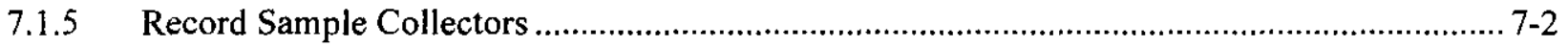

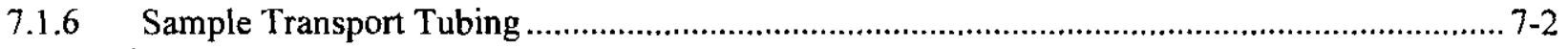

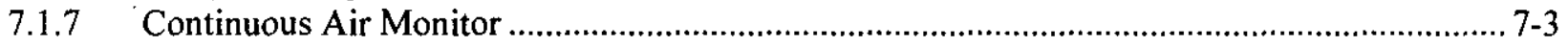

7.2 TECHNICAL SPECIFICATIONS PERTAINING TO THE EFFLUENT MONITORING ..... 7-3

8.0 HISTORICAL MONITORING/SAMPLING DATA FOR EFFLUENT STREAMS .............. 8-1

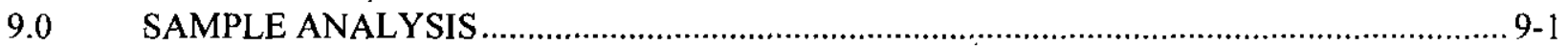

9.1 ANALYTICAL LABORATORY PROCEDURES ......................................................... 9-1

9.1.1 Record Sample Exchange .............................................................................................. 9-1

9.1.2 Continuous Air Monitor Filter Exchange ...................................................................... 9-1

9.1.3 Sample Data Examination and Delivery ...................................................................... 9-1

9.1.4 Laboratory Sample Analysis Instructions ..................................................................... 9-1

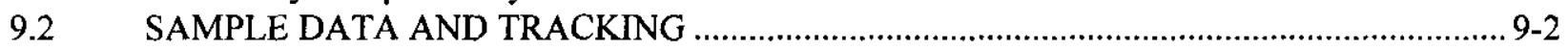

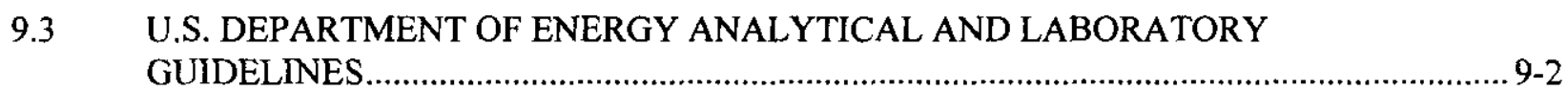

10.0 NOTIFICATIONS AND REPORTING REQUIREMENTS …................................ 10-1

10.1 ENVIRONMENTAL OCCURRENCE …............................................................... 10-1

10.2 PERIODIC ROUTINE EFFLUENT MONITORING REPORTS …............................... 10-1

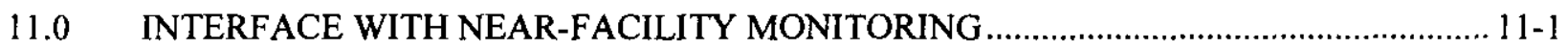

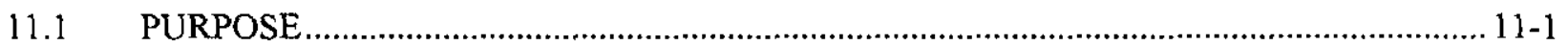

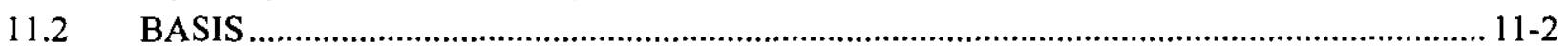

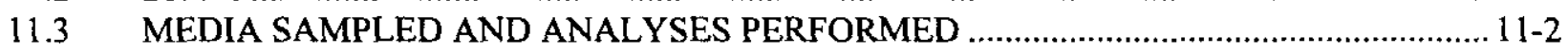

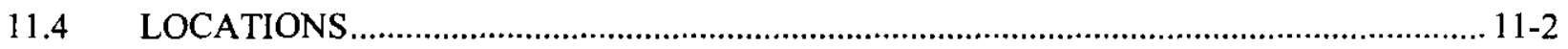

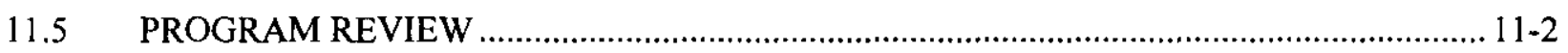

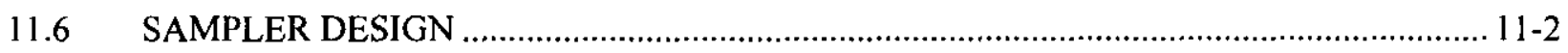




\section{CONTENTS (cont)}

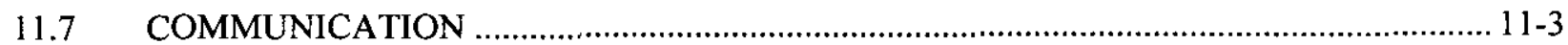

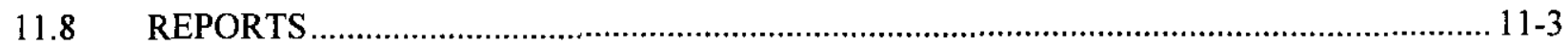

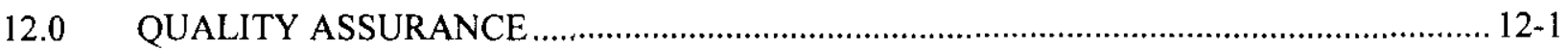

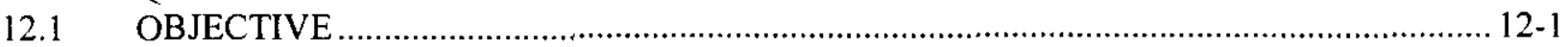

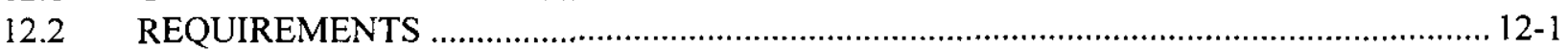

I INTERNAL AND EXTERNAL PLAN REVIEW .................................................... 13-1

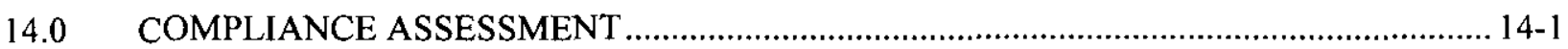

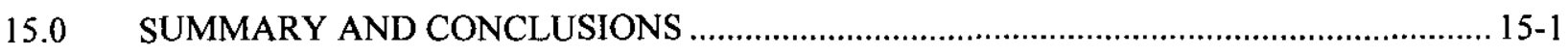

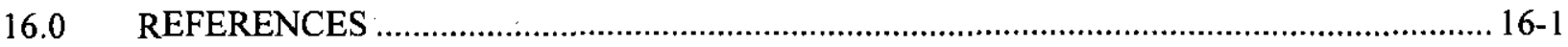

\section{FIGURES}

Figure 2-1. Drum Waste Flow in the Waste Receiving and Processing Facility................................F2-1

Figure 5-1. Gaseous Effluent Flow Diagram..................................................................................

\section{TABLES}

Table 2-1. Radioactive Material Potential Source Term.

Table 2-2. Waste Receiving and Processing Estimated Hazardous Material Potential Source

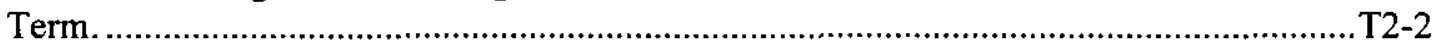

Table 3-1. Applicable Regulations, Standards, and Permits ...................................................... T3-1

Table 4-1. Waste Receiving and Processing Facility Gaseous and Liquid Effluent Streams.............T4-1

Table 5-1. Technical Design Data for the Waste Receiving and Processing Facility Exhaust

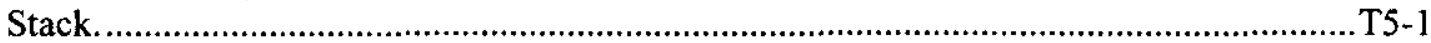

Table 9-1. Minimum Detectable Concentrations for Specific Radionuclides as Measured in Air Samples.

Table 9-2. Data Analyses and Statistical Treatment. 
HNF-EP-0885-1

This page intentionally left blank. 


\title{
TERMS
}

\author{
ABCASH \\ AED \\ ALARA \\ ANSI \\ ASRS \\ BACT \\ BARCT \\ BCAA \\ CAM \\ CERCLA \\ CFR \\ CWC \\ DOE \\ DOE RL \\ ECOLOGY \\ EDE \\ EDP \\ EM \\ EMP \\ EMS \\ EPA \\ FEMP \\ $\mathrm{FH}$ \\ GEA \\ HEPA \\ HNF \\ HVAC \\ INEEL \\ LLW \\ MEI \\ NDA \\ NDE \\ NESHAPS \\ NPDES \\ OEMP \\ Automated Bar Coding of Air Samples at Hanford \\ aerodynamic equivalent diameter \\ as low as reasonably achievable \\ American National Standards Institute \\ automated stacker and retrieval system \\ best available control technology \\ best available radionuclide control technology \\ Benton Clean Air Authority \\ continuous air monitor \\ Comprehensive Environmental Response, Compensation, and Liability Act of \\ 1980 \\ Code of Federal Regulations \\ Central Waste Complex \\ U.S. Department of Energy \\ U.S. Department of Energy, Richland Operations Office \\ Washington State Department of Ecology \\ effective dose equivalent \\ electronic data processing \\ Environmental Monitoring \\ effluent monitoring plan \\ environmental monitoring/sampling system \\ U.S. Environmental Protection Agency \\ facility effluent monitoring plan \\ Fluor Hanford \\ gamma energy assay \\ high-efficiency particulate air \\ Hanford Nuclear Facility (document identifier) \\ heating, ventilation, and air conditioning \\ Idaho National Environmental Engineering Laboratory \\ low-level waste \\ maximum exposed individual \\ nondestructive assay \\ nondestructive examination \\ National Emissions Standards for Hazardous Air Pollutants \\ National Pollutants Discharge Elimination System \\ Operational Environmental Monitoring Program
}




\section{TERMS (CONT)}

$\begin{array}{ll}\text { PAN } & \begin{array}{l}\text { passive active neutron } \\ \text { plant control system } \\ \text { PCS }\end{array} \\ \text { PHMC } & \begin{array}{l}\text { Project Hanford Management Contract } \\ \text { PNNific Northwest National Laboratory }\end{array} \\ \text { QA } & \begin{array}{l}\text { quality assurance } \\ \text { quality assurance project plan }\end{array} \\ \text { QAPjP } & \begin{array}{l}\text { radioactivity concentration guide } \\ \text { Resource Conservation and Recovery Act of } 1976 \\ \text { reportable quantity }\end{array} \\ \text { RCG } & \begin{array}{l}\text { toxic best available control technology } \\ \text { RQ }\end{array} \\ \text { transuranic (waste) } \\ \text { TRACT }\end{array}$




\subsection{FACILITY EFFLUENT MONITORING PLAN FOR THE WASTE RECEIVING AND PROCESSING FACILITY}

It is the policy of the U.S. Department of Energy (DOE) and Fluor Hanford (FH) to conduct effluent monitoring to determine if the public and the environment are protected adequately during DOE operations on the Hanford Site, and whether these operations are in compliance with DOE and other applicable federal, state, and local emission standards and requirements.

Since 1970 , a large quantity of radioactive solid waste has been produced throughout the DOE complex. Until 1988, much of this waste was buried in retrievable storage with the intention of eventually repackaging the waste and sending the waste to final disposal; this is referred to as retrievable waste. Waste generated after 1988 is referred to as newly generated waste, and this is the primary feed stream for the Waste Receiving and Processing Facility (WRAP).

WRAP, located in the 200 West Area of the Hanford Site, provides waste receipt, confirmation, repackaging, certification, and/or storage of dangerous, mixed, and radioactive waste from onsite generating units or from offsite generators, TSD units, or as a result of operations. Mixed and/or radioactive waste is treated in WRAP.

\subsection{PURPOSE}

The purpose of this facility effluent monitoring plan (FEMP) is to assess the magnitude of routine and potential liquid and airborne effluent releases from WRAP to determine compliance and to verify that the effluent monitoring systems and sampling programs meet applicable federal, state, and local regulations. Where potential environmental problems are identified from monitoring, an evaluation is needed to determine if any remedial actions or mitigation measures would be required.

\subsection{SCOPE}

The scope of this document includes program plans for monitoring and characterizing radioactive and nonradioactive hazardous materials discharged in WRAP effluents. This FEMP includes complete documentation for both airborne and liquid effluent monitoring systems that monitor radioactive and nonradioactive hazardous pollutants that could be discharged to the environment under routine and/or upset conditions. This FEMP describes the airborne and liquid effluent paths and the associated sampling and monitoring systems of WRAP.

\subsection{DISCUSSION}

The characterization of the radioactive and nonradioactive constituents in each effluent stream provides the underlying rationale for the sampling and monitoring programs. The method of characterization discussed in this plan identifies potential pollutants at the point of generation and tracks the constituents in effluent streams as the constituents move from the generation point to the point of discharge.

Included is information from the FEMP determination for WRAP, evaluating whether or not WRAP meets the criteria required for a FEMP (WHC-EP-0438-1). 
A FEMP is required if the total projected dose from radionuclides exceeds 0.1 mrem per year effective dose equivalent (EDE) for an offsite individual. Also, a FEMP is required if any regulated material discharged over a 24 -hour period from a facility exceeds $100 \%$ of the reportable quantity (RQ) as listed in 40 Code of Federal Regulation (CFR) 302.4 or is designated a permitted quantity in Washington Administrative Code (WAC) 173-303-70 through 173-303-103. A FEMP also is required if a liquid effluent is regulated by the National Pollutants Discharge Elimination System (NPDES) and contains radionuclides that would cause any person consuming that effluent to receive an EDE greater than 4.0 mrem per year. DOE Orders also require a FEMP evaluation to consider anticipated facility upset conditions.

WRAP has three engineered liquid effluent disposal pathways to the environment: the sanitary sewer and two industrial wastewater sewers leading to engineered disposal units covered by three sitewide permits under WAC 173-216, State Waste Discharge Permit Program. These liquid effluents are not in the scope of this FEMP because the effluents do not contain radionuclides, regulated material at or near reportable quantities, and are not regulated by the NPDES. Because potential emissions, i.e., without control devices in place, from the WRAP main exhaust stack have been estimated to have the potential to emit greater than the 0.1 mrem per year limit set by the National Emissions Standards for Hazardous Air Pollutants (NESHAPs), a FEMP is required. Details of the stack effluent stream and the associated monitoring and sampling systems are included in this FEMP. 
HNF-EP-0885 Rev. 1

\subsection{FACILITY DESCRIPTION}

WRAP, located in the 200 West Area, is constructed of pre-insulated, prefinished metal, interlocking roof, and wall sandwich panels. The outside dimensions are approximately 61 meters by 73 meters. WRAP has waste processing, shipping and receiving areas; mechanical, electrical, heating, ventilation, and air conditioning (HVAC) rooms, as well as administrative areas all located on the 4,066 square meter main floor; and a control room, computer room, and nonradiological HVAC equipment located on the 215 square meter second floor.

\subsection{BRIEF PROCESS DESCRIPTION}

Throughout the 50 years of Hanford Site operations, large quantities of radioactive solid waste has been generated. The majority of this waste was buried. From 1970 until 1988, any of this waste designated as transuranic (TRU) waste was buried in retrievable storage. This constitutes the retrievable waste stream for WRAP. Because of changing designation requirements for TRU waste, it is estimated that 50 percent of the retrievable waste will be TRU and/or TRU mixed (TRUM) and 50 percent will be low-level waste (LLW) and/or mixed waste (MW). All potential TRU waste generated since 1988 is stored in aboveground storage units. This waste and any TRU waste generated in the future are considered newly generated waste. Newly generated waste, including TRU and non-TRU waste for verification, treatment, and/or repackaging, is the feed stream for WRAP.

Waste entering WRAP, either retrieved or newly generated, is packaged in drums or boxes. Newly generated TRU waste in standard waste boxes and LLW in boxes are received at WRAP for verification and confirmation. The boxes undergo nondestructive examination (NDE) and nondestructive assay (NDA) only. Capabilities are not provided within WRAP to open and sort waste contents in boxes. If noncompliant items or conditions are determined after NDE or NDA, the boxes are returned to the generating unit or moved to storage elsewhere for future processing. Because the boxed waste will not add to the total radioactive or restricted material emissions from WRAP, boxed waste is not covered in this document.

Both newly generated and retrieved drummed waste can pass through three main areas during reprocessing at WRAP; shipping and receiving area, NDE and NDA area, and the actual reprocessing area (refer to Figure 2-1 for process flow diagram).

\subsubsection{Shipping and Receiving Area}

The shipping and receiving area provides approximately 350 square meters of interim storage for incoming and outgoing waste. Incoming waste containers and the respective delivery vehicles visually are inspected, the associated paperwork is reviewed, and a radiological survey is performed. Any discrepancies noted are resolved either with the shipper and/or generating unit or flagged for resolution by WRAP operations personnel, or the waste containers returned to the generating unit.

Interim storage within the shipping and receiving area is handled by an automated stacker and retrieval system (ASRS). Segregation of the waste occurs within the ASRS by using containment pallets. Waste is segregated by container type and compatibility. Along with the administratively controlled placement of containers within the ASRS, containment pallets could be used to contain any leaks. 
Space is provided to accommodate the storage of at least 216 containers. A concrete wall provides shielding around the ASRS for radiological protection of personnel. Space also is provided in the shipping and receiving area for storage of up to eight waste boxes. Container storage locations are recorded on a computerized tracking system that selects individual containers for processing to match current process requirements.

Containers shipped from WRAP are examined visually to ensure acceptable condition, proper identification, marking, labeling, and closure. Appropriate marking and labels are selected, completed, and applied to comply with U.S. Department of Transportation (49 CFR) and WAC 173-303 labeling requirements. Each container is weighed and radiological surveys are performed and documented.

Most LLW containers are transported by flatbed trucks or enclosed vans to the Low-Level Burial Grounds or via fork truck to the Central Waste Complex (CWC). MW and TRU waste ready for interim storage are transported to the CWC.

TRU and TRUM waste containers ready for shipment are moved to the loading and storage area in WRAP. In this area, the containers are stretch-wrapped in a seven-drum configuration for loading into TRUPACT'-II shipping casks. Two seven-packs of containers or two standard waste boxes (SWB ${ }^{2}$ ) are loaded into each cask. Up to three casks can be on each trailer. TRU waste is shipped to the Waste Isolation Pilot Plant (WIPP) for disposal or to another approved disposal site.

\subsubsection{Nondestructive Examination and Nondestructive Assay Area}

The NDE and NDA areas provide approximately 700 square meters for radiography and NDA equipment. The NDE equipment uses penetrating radiation to examine the content of each incoming waste container. NDA equipment is used to determine the radionuclide content of each waste container.

Nondestructive examination systems are used to identify dense waste items that could influence NDA, to indicate the physical appearance of the waste, and to identify if liquids or other noncompliant ${ }^{3}$ waste forms are present. Such identifications are noted in the data management system to ensure that noncompliant items are removed in a waste process glovebox within the process area.

NDA indicates the radionuclide content and distribution in the waste. Two assay techniques are used in WRAP: passive-active neutron (PAN) interrogation and segmented gamma energy scan. PAN counting methods are used to detect and measure the quantity of uranium, plutonium, curium, and californium isotopes. The gamma energy equipment assays uranium-233, uranium-235, some plutonium isotopes, neptunium-237, americium-241, americium-243, and fission and activation products. These

\footnotetext{
' Transuranic package transporter.
}

${ }^{2} \mathrm{SWB}$ is the name of a specific box designed expressly for transport in a TRUPACT-II to the WIPP repository or another approved disposal site. Each SWB is approximately 139 centimeters wide by 162 centimeters long by 83 centimeters high with round ends with either a welded or gasket bolted lid. Each SWB is constructed of 12-gauge painted carbon steel with carbon steel reinforcement and is equipped with one or more carbon composite filtered vents. Each SWB has an empty weight of 368 kilograms with a nominal capacity of 1.8 cubic meters and 2,727 kilograms gross.

${ }^{3}$ Noncompliant waste refers to materials that cannot be accepted for transportation or disposal at WIPP or that cannot be accepted for disposal on the Hanford Facility without further reprocessing. 
measurements are used to sort the waste as either TRU or low-level and to group the LLW into Category 1, Category 3, or greater than Category 3 (HNF-EP-0063).

Separate NDE and NDA lines are provided for containers and boxes. Space is provided within the NDE and NDA areas for the storage of 12 waste containers.

Containers certified in the NDE and NDA areas are routed to the shipping and receiving area. Containers not meeting confirmation requirements are processed through WRAP or stored at CWC pending treatment capability or resolution of noncompliant condition.

\subsubsection{Process Area}

The process area provides approximately 650 square meters and is designed to provide secondary containment when waste drums are opened in the process gloveboxes. Automatic dry chemical fire extinguishing systems are provided inside the gloveboxes. Two separate lines are provided to segregate LLW from TRU waste.

In the process gloveboxes, drums are opened, the contents sorted, LLW and empty TRU containers are compacted, compliant waste is loaded into new drums, and noncompliant waste items are transferred to either the low-level restricted waste management (RWM) glovebox or the TRU RWM glovebox.

Samples are taken, field screening is performed, and limited treatment occurs on noncompliant items in a RWM glovebox. Venting or puncturing of aerosol cans also occurs within the RWM gloveboxes. The sampling and screening occurs for both verification and/or characterization (to determine proper handling and/or laboratory analysis methods), depending on the waste stream.

Because much of the waste is contained in small inner packages inside the drums, a NDE system is located within the process gloveboxes to assist in the identification of noncompliant items. A small NDA system located within the TRU waste process glovebox is used to identify gram loading of waste packages.

Limited treatment of noncompliant waste is performed in the RWM gloveboxes. Noncompliant materials include, but are not limited to, the following:

- Aerosol cans

- Reactive metals

- Chelating compounds

- Chemically incompatible materials

- Corrosives

- Explosives

- Gas cylinders not permanently vented

- Lead

- Free liquids

- Mercury

- Particulate materials

- Pyrophoric materials.

Waste requiring treatment other than what WRAP can provide is repackaged, labeled, and transferred to CWC for storage pending identification or development of appropriate treatment. 
Waste sampling occurs in the RWM gloveboxes, and to a lesser degree in the process gloveboxes, to determine the presence and characteristics of any dangerous waste constituents. Field screening techniques are used as much as practical to assist in the characterization of the waste, narrowing down the list of potential analytes for laboratory analysis.

Samples of waste are transferred to the sample management area for packaging and documentation completion, and sent to an onsite laboratory or shipped offsite to a laboratory for analysis. Samples are collected and analyzed in accordance with WAC 173-303-110 and SW-846, or equivalent approved methods.

Interim storage is provided for empty drums and waste containers awaiting laboratory analysis. The storage area is surrounded by concrete shield walls and roof to protect operating personnel. The total space provided is for 24 containers. If there is insufficient space in this storage area, excess drums are stored either in the ASRS located in the shipping and receiving area or transferred elsewhere.

\subsubsection{Sample Management Area}

The sample management area receives samples from the process area and RWM gloveboxes. The sample management area is used to package samples for transport to appropriate onsite or offsite analytical laboratories. All samples have a bar code label and are accompanied by chain-of-custody documentation.

The sample management area contains storage space for samples, which includes refrigerated storage and laboratory supplies.

\subsection{IDENTIFICATION AND CHARACTERIZATION OF POTENTIAL SOURCE TERMS}

Tables 2-1 and 2-2 summarize the source term information presented in the FEMP determination for both radioactive and regulated materials. 


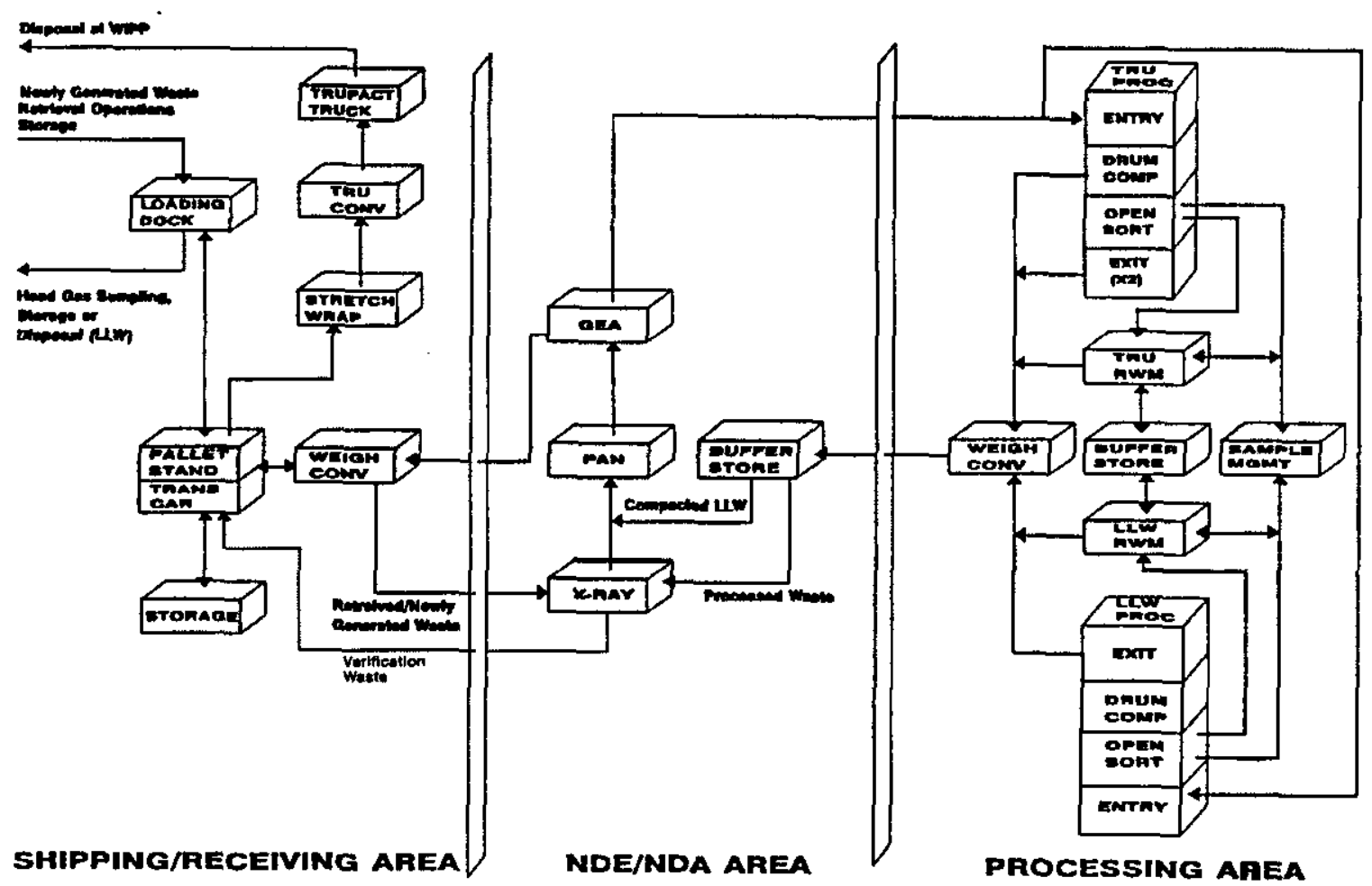

H99100202.101R1

$\begin{array}{ll}\text { COMP } & =\text { compaction } \\ \text { CONV } & =\text { conveyor } \\ \text { GEA } & =\text { gamma energy analysis } \\ \text { LLW } & =\text { low-level waste } \\ \text { MGMT } & =\text { management } \\ \text { NDA } & =\text { nondestructive assay } \\ \text { NDE } & =\text { nondestructive examination } \\ \text { PAN } & =\text { passive active neutron } \\ \text { PROC } & =\text { process } \\ \text { RWM } & =\text { restricted waste management } \\ \text { TRU } & =\text { transuranic } \\ \text { TRUPACT } & =\text { transuranic package transporter } \\ \text { WIPP } & =\text { Waste Isolation Pilot Plant. }\end{array}$

Figure 2-1. Drum Waste Flow in the Waste Receiving and Processing Facility. 
HNF-EP-0885 Rev. 1

This page intentionally left blank. 
Table 2-1. Radioactive Material Potential Source Term.

\begin{tabular}{|c|c|c|c|c|c|c|}
\hline Radioisotopes & $\begin{array}{c}\text { Process rate } \\
\qquad \mathrm{Ci} / \mathrm{yr}\end{array}$ & $\begin{array}{c}\text { Release } \\
\text { rate } \\
\text { factor }\end{array}$ & $\begin{array}{l}\text { Emission } \\
\text { (Ci/year) }\end{array}$ & $\begin{array}{l}\text { Modeled } \\
\text { dose factor } \\
(\mathrm{mrem} / \mathrm{Ci})\end{array}$ & $\begin{array}{l}\text { Unabated } \\
\text { emissions } \\
\text { (mrem/yr) }\end{array}$ & $\begin{array}{l}\text { Percent of } \\
\text { total }\end{array}$ \\
\hline \multicolumn{7}{|l|}{ Volatiles } \\
\hline $\mathrm{H}-3$ & $2.00 \mathrm{E}+00$ & $1.00 \mathrm{E}+00$ & $2.00 \mathrm{E}+00$ & $0.00 \mathrm{E}+00$ & $0.00 \mathrm{E}+00$ & $0.00 \mathrm{E}+00$ \\
\hline$C-14$ & $7.40 \mathrm{E}-01$ & $1.00 \mathrm{E}+00$ & $7.40 \mathrm{E}-01$ & $0.00 \mathrm{E}+00$ & $0.00 \mathrm{E}+00$ & $0.00 \mathrm{E}+00$ \\
\hline $\mathrm{Kr}-85$ & $1.74 \mathrm{E}+05$ & $1.00 \mathrm{E}+00$ & $1.74 \mathrm{E}+05$ & $0.00 \mathrm{E}+00$ & $0.00 \mathrm{E}+00$ & $0.00 \mathrm{E}+00$ \\
\hline \multicolumn{7}{|l|}{ Particulates } \\
\hline Co-60 & $3.60 \mathrm{E}+02$ & $1.00 \mathrm{E}-03$ & $3.60 \mathrm{E}-01$ & $1.72 \mathrm{E}-02$ & $6.19 \mathrm{E}-03$ & $4.80 \mathrm{E}-03$ \\
\hline $\mathrm{Sr} / \mathrm{Y}-90$ & $1.73 \mathrm{E}+05$ & $1.00 \mathrm{E}-03$ & $1.73 \mathrm{E}+02$ & $2.60 \mathrm{E}-02$ & $4.50 \mathrm{E}+00$ & $3.49 \mathrm{E}+00$ \\
\hline $\mathrm{Ru} / \mathrm{Rh}-106$ & $8.99 \mathrm{E}+00$ & $1.00 \mathrm{E}-03$ & $8.99 \mathrm{E}-03$ & $1.24 \mathrm{E}-02$ & $1.11 \mathrm{E}-04$ & $8.64 \mathrm{E}-05$ \\
\hline $\mathrm{Cs} / \mathrm{Ba}-137$ & $1.76 \mathrm{E}+05$ & $1.00 \mathrm{E}-03$ & $1.76 \mathrm{E}+02$ & $1.42 \mathrm{E}-02$ & $2.50 \mathrm{E}+00$ & $1.94 \mathrm{E}+00$ \\
\hline $\mathrm{Ce}-141$ & $1.08 \mathrm{E}-30$ & $1.00 \mathrm{E}-03$ & $1.08 \mathrm{E}-33$ & $8.14 \mathrm{E}-03$ & $8.79 \mathrm{E}-36$ & $6.81 \mathrm{E}-36$ \\
\hline $\mathrm{Ce} / \mathrm{Pr}-144$ & $1.97 \mathrm{E}+01$ & $1.00 \mathrm{E}-03$ & $1.97 \mathrm{E}-02$ & $8.14 \mathrm{E}-03$ & $1.60 \mathrm{E}-04$ & $1.24 \mathrm{E}-04$ \\
\hline $\mathrm{Pm}-147$ & $2.25 \mathrm{E}+03$ & $1.00 \mathrm{E}-03$ & $2.25 \mathrm{E}+00$ & $1.16 \mathrm{E}-03$ & $2.61 \mathrm{E}-03$ & $2.02 \mathrm{E}-03$ \\
\hline Eu-155 & $8.23 \mathrm{E}-01$ & $1.00 \mathrm{E}-03$ & 8.23E-04 & $1.42 \mathrm{E}-02$ & $1.17 \mathrm{E}-05$ & $9.06 \mathrm{E}-06$ \\
\hline Th-232 & $3.11 \mathrm{E}-01$ & $1.00 \mathrm{E}-03$ & $3.11 \mathrm{E}-04$ & $4.83 E+00$ & $1.50 \mathrm{E}-03$ & $1.16 \mathrm{E}-03$ \\
\hline U-233 & $3.71 \mathrm{E}+01$ & $1.00 \mathrm{E}-03$ & $3.71 \mathrm{E}-02$ & $1.92 \mathrm{E}+00$ & $7.12 \mathrm{E}-02$ & $5.52 \mathrm{E}-02$ \\
\hline U-235 & $5.05 \mathrm{E}+00$ & $1.00 \mathrm{E}-03$ & $1.05 \mathrm{E}-03$ & $1.76 \mathrm{E}+00$ & $1.85 \mathrm{E}-03$ & $1.43 E-03$ \\
\hline $\mathrm{Np}-237$ & $1.15 \mathrm{E}+00$ & $1.00 \mathrm{E}-03$ & $1.15 \mathrm{E}-03$ & $7.05 \mathrm{E}+00$ & $8.11 \mathrm{E}-03$ & $6.28 \mathrm{E}-03$ \\
\hline Pu-238 & $7.19 \mathrm{E}+03$ & $1.00 \mathrm{E}-03$ & $7.19 \mathrm{E}+00$ & $4.76 \mathrm{E}+00$ & $3.42 \mathrm{E}+01$ & $2.65 \mathrm{E}+01$ \\
\hline Pu-239 & $1.25 \mathrm{E}+04$ & $1.00 \mathrm{E}-03$ & $1.25 \mathrm{E}+01$ & $5.15 \mathrm{E}+00$ & $6.44 \mathrm{E}+01$ & $4.99 \mathrm{E}+01$ \\
\hline $\mathrm{Pu}-240$ & $2.99 \mathrm{E}+03$ & $1.00 \mathrm{E}-03$ & $2.99 E+00$ & $5.14 \mathrm{E}+00$ & $1.54 \mathrm{E}+01$ & $1.19 \mathrm{E}+01$ \\
\hline $\mathrm{Pu}-241$ & $2.68 \mathrm{E}+04$ & $1.00 \mathrm{E}-03$ & $2.68 \mathrm{E}+01$ & 8.17E-02 & $2.19 \mathrm{E}+00$ & $1.70 \mathrm{E}+00$ \\
\hline $\mathrm{Pu}-242$ & $1.70 \mathrm{E}-01$ & $1.00 \mathrm{E}-03$ & $1.70 \mathrm{E}-04$ & $5.15 E+00$ & $8.76 \mathrm{E}-04$ & $6.79 \mathrm{E}-04$ \\
\hline Am-241 & $2.89 \mathrm{E}+02$ & $1.00 \mathrm{E}-03$ & $2.89 \mathrm{E}-01$ & $7.79 \mathrm{E}+00$ & $2.25 \mathrm{E}+00$ & $1.75 \mathrm{E}+00$ \\
\hline Am-243 & $4.51 \mathrm{E}+02$ & $1.00 \mathrm{E}-03$ & $4.51 \mathrm{E}-01$ & $7.79 \mathrm{E}+00$ & $3.51 \mathrm{E}+00$ & $2.72 \mathrm{E}+00$ \\
\hline $\mathrm{Cm}-245$ & $3.50 \mathrm{E}+00$ & $1.00 \mathrm{E}-03$ & $3.50 \mathrm{E}-03$ & $0.00 \mathrm{E}+00$ & $0.00 \mathrm{E}+00$ & $0.00 \mathrm{E}+00$ \\
\hline Cf-252 & $7.37 \mathrm{E}+01$ & $1.00 \mathrm{E}-03$ & $7.37 \mathrm{E}-02$ & $0.00 \mathrm{E}+00$ & $0.00 \mathrm{E}+00$ & $0.00 \mathrm{E}+00$ \\
\hline Totals & $5.76 \mathrm{E}+05$ & & & & $1.29 \mathrm{E}+02$ & \\
\hline
\end{tabular}

Note: Based on processing 20,475 drums/yr

$\mathrm{Ci} / \mathrm{yr}=$ curies per year

mrem $/ \mathrm{Ci}=$ millirem per curie

$\mathrm{mrem} / \mathrm{yr}=$ millirem per year 
Table 2-2. Waste Receiving and Processing Estimated Hazardous Material Potential Source Term.

Listed hazardous chemical amounts compared to 40 CFR 302.4 reportable quantities.

\begin{tabular}{|c|c|c|c|c|c|}
\hline \multirow{2}{*}{$\begin{array}{l}\text { Listed hazardous } \\
\text { substances }\end{array}$} & \multirow{2}{*}{$\begin{array}{l}\text { Annual } \\
\text { material } \\
\text { processed } \\
\text { in } \mathrm{kg} / \mathrm{yr}\end{array}$} & \multicolumn{2}{|c|}{ Total Zone 1 emissions* } & \multirow{2}{*}{$\begin{array}{l}\text { Hazardous } \\
\text { chemical } \\
\text { reportable } \\
\text { quantity } \\
\mathrm{kg} / 24 \text {-hour } \\
\text { period } \\
\end{array}$} & \multirow{2}{*}{$\begin{array}{c}\text { Percent of } \\
\text { reportable } \\
\text { quantity } \\
\text { released per } \\
\text { day, } 365 \text { days } \\
\text { per year }\end{array}$} \\
\hline & & $\begin{array}{c}\text { Annual } \\
\text { average } \\
\text { emission rate } \\
\mathrm{kg} / \mathrm{yr}\end{array}$ & $\begin{array}{l}\text { Peak daily } \\
\text { rate } \\
\mathrm{kg} / \text { day }^{* *}\end{array}$ & & \\
\hline carbon tetrachloride & 313 & 18.1 & 0.5 & 2,270 & 0.02 \\
\hline formaldehyde & 13 & 0.09 & 0.0 & 454 & $<0.001$ \\
\hline xylene & 422 & 1.9 & 0.05 & 454 & 0.01 \\
\hline toluene & 381 & 5.4 & 0.15 & 454 & 0.03 \\
\hline 2-butanone & 327 & 17.4 & 0.48 & 2,270 & 0.02 \\
\hline 4-methyl 2- & 68 & 0.23 & 0.01 & 2,270 & $<0.001$ \\
\hline acetone & 313 & 37.0 & 1.01 & 2,270 & 0.045 \\
\hline ethyl benzene & 82 & 0.36 & 0.01 & 454 & 0.002 \\
\hline methanol & 531 & 32.7 & 0.90 & 2,270 & 0.04 \\
\hline n-butyl alcohol & 27 & 0.09 & 0.01 & 2,270 & $<0.001$ \\
\hline ammonium & 27 & 10.6 & 0.29 & 454 & 0.064 \\
\hline dichlorodifluoro & 490 & 489.9 & 13.4 & 2,270 & 0.6 \\
\hline polychlorinated & 272 & 0.27 & 0.01 & 4.54 & 0.22 \\
\hline cadmium & 10 & 0.01 & 0.00 & .454 & $<0.001$ \\
\hline mercury & 10 & 0.01 & 0.00 & .454 & $<0.001$ \\
\hline lead (3) & 2,722 & 2.7 & 0.07 & .454 & 15 \\
\hline
\end{tabular}

$\mathrm{kg} /$ day $=$ kilogram(s) per day.

$\mathrm{kg} / \mathrm{yr}=$ kilogram(s) per year.

* The primary emission of hazardous substances comes from Zone 1.

** Based on upset condition. 
HNF-EP-0885 Rev. 1

\subsection{APPLICABLE REGULATIONS}

Conditions and requirements for monitoring existing or potential releases of radioactive and other chemicals to the environment are contained in DOE Orders; federal, state, and local laws; regulations; and permits. Table 3-1 gives a brief summary of the regulations and standards applicable to this FEMP. Because regulations enforced by agencies could differ, $\mathrm{FH}$ might enforce more restrictive requirements as a matter of policy. These policies can be found in the PHMC Environmental Protection policies and procedures: HNF-PRO-450, Air Quality-Radioactive Emissions Program, HNF-PRO-453, Spill and Release Reporting, HNF-PRO-456, Water Quality Program, HNF-PRO-1929, Requirements Management, and HNF-PRO-2364, Radioactive Airborne Effluent Sampling.

\subsection{U.S. DEPARTMENT OF ENERGY ORDERS}

DOE Order 5400.1, General Environmental Protection Program, requires a written environmental monitoring plan for each site, facility, or process that uses, generates, releases, or manages significant pollutants or hazardous materials. The plan must include the rationale and design criteria for the monitoring program, as well as describe the extent and frequency of the monitoring analysis. The plan also must contain quality assurance (QA) requirements, program implementation procedures, directions for preparation and implementation of reports, and directions for identification and discussion of effluent monitoring and environmental surveillance.

The effluent monitoring portion of the plan must verify compliance with applicable regulations and DOE Orders, i.e., DOE 5400.5, Radiation Protection of the Public and the Environment. The plan also should evaluate the effectiveness of treatment; identify potential environmental problems; evaluate the need for remedial action or mitigation measures; support permit revision and/or reissuance; and detect, characterize, and report unplanned releases. Compliance with the requirements of DOE Order 5400.1 could be demonstrated based on calculations from monitoring and surveillance programs.

DOE Order 5820.2A, Radioactive Waste Management, establishes policies, guidelines, and minimum requirements by which the DOE manages its radioactive and mixed waste and contaminated facilities.

\subsection{FEDERAL REGULATIONS}

Federal regulations applicable to this FEMP are discussed in the following sections.

\subsubsection{National Emission Standards for Hazardous Air Pollutants (40 CFR 61, Subpart H)}

Subpart H, "National Emission Standards for Emissions of Radionuclides Other Than Radon from Department of Energy Facilities" (40 CFR 61) establishes exposure limits and monitoring requirements.

The exposure limits for a member of the public from radionuclide air emissions is an EDE not to exceed 10 mrem per year. Compliance with this standard is measured by calculating the highest EDE where a person resides or abides using an EPA-approved method.

Emissions of radionuclides must be measured at all release points that have a potential to discharge radionuclides into the air in quantities that could cause an EDE in excess of 1 percent of the standard. If the EDE caused by all emissions is less than 1 percent of the standard, the facility is exempt from the 
EPA monitoring requirements. All radionuclides that could contribute greater than 10 percent of the potential EDE for a release point are measured individually. For other release points that have a potential to release radionuclides into the air, periodic confirmatory measurements are made to verify low emissions.

To determine whether a release point is subject to emission measurement requirements, it is necessary to evaluate the potential for radionuclide emissions for that release point. In evaluating the potential of a release point to discharge radionuclides into the air, the estimated radionuclide release rates is based on the discharge of the effluent stream that would result if all pollution control equipment did not exist, but the facility operations otherwise were normal.

Subpart $\mathrm{H}$ also states that major stacks be monitored continuously with an in-line detector or representative samples of the effluent stream withdrawn continuously from the sampling site following the guidance presented in American National Standards Institute (ANSI) N13.1. The EPA also approved an Alternate Method for sampling using single point sampling with a shrouded probe. The requirements for continuous sampling are applicable to batch processes when the unit is in operation. Periodic sampling (grab samples) may be used only with prior EPA approval. Such approval might be granted in cases where continuous sampling is not practical and radionuclide emission rates are relatively constant. In such cases, grab samples can be collected with sufficient frequency to provide a representative sample of the emissions.

\subsubsection{State Operating Permit Program (40 CFR 70)}

This regulation defines the minimum elements required by the Federal Water Pollution Control Act of 1972 for state operating permit programs and corresponding standards and procedures by which the administrator will approve, oversee, and withdraw approval of state operating permit programs.

\subsubsection{Identification and Listing of Hazardous Waste (40 CFR 261)}

This part identifies solid waste that is subject to regulation as a hazardous waste.

\subsubsection{Designation, Reportable Quantities, and Notification (40 CFR 302)}

The regulations in "EPA Designation, Reportable Quantities, and Notification Requirements for Hazardous Substances Under CERCLA" (40 CFR 302) designate hazardous substances and identify reportable quantities and notification requirements for release of these hazardous substances under the Comprehensive Environmental Response, Compensation, and Liability (CERCLA) Act of 1980 and the Safe Drinking Water Act of 1974, as amended.

Any unpermitted release of any of these designated hazardous substances must be reported. Therefore, if the possibility exists for a facility to release any of the designated substances, waste streams must be monitored for their presence and monitoring practices must be provided in a FEMP.

\subsection{INDUSTRY STANDARDS UNDER AMERICAN NATIONAL STANDARDS INSTITUTE}

Industry standards are discussed in the following sections. 


\subsubsection{Guide to Sampling Airborne Radioactive Materials in Nuclear Facilities (ANSI N13.1)}

Note: This standard is currently under revision. When issued, the standard will recommend performance based sampling that would allow the use of single point sampling, i.e., a shrouded probe.

The primary objective for sampling airborne radioactivity in effluents is to measure the release of radioactive materials to the environment. This is accomplished through sampling near the point of release. The objective of ANSI N13.1 is to set forth the principles that apply in obtaining valid samples of airborne radioactive materials and to prescribe acceptable methods and materials for gaseous and particulate sampling.

ANSI N13.1 is limited to the collection of samples and does not address measurement of the radioactive materials collected. The exclusion of radiochemical measurement from the scope must not be construed to mean that the measurement of samples is of lesser importance than sampling.

\subsubsection{Specification and Performance of Onsite Instrumentation for Continuously Monitoring Radioactivity in Effluents (ANSI N42.18)}

The objective of continuously monitoring instrumentation is to measure the quantity and/or the rate of release of radionuclides in the effluent stream and to provide useful documentation for scientific and logical purposes. This standard applies to continuous monitors that measure normal releases, detect inadvertent releases, show general trends, and annunciate radiation levels that have exceeded predetermined values. This standard specifies detection capabilities, physical operating limits, reliability, calibration requirements, and sets minimum performance requirements for effluent monitoring.

\subsection{WASHINGTON STATE REGULATIONS}

Applicable Washington State regulations are discussed in the following sections.

\subsubsection{Air Operating Permit Program (WAC 173-401)}

The provisions in this regulation establish the element of a comprehensive Washington State air operating permit program consistent with the requirements of the Federal Clean Air Act of 1977. All sources (hazardous and radionuclides pollutants) subject to this regulation will have a permit to operate that ensures compliance with all applicable requirements.

\subsubsection{Ambient Air Quality Standards and Emission Limits for Radionuclides (WAC 173-480)}

Although the standard for Washington State establishes a 25-mrem per year (cumulative) dose limit for public exposure to radionuclide emissions, facilities must comply with the more current and more restrictive of federal, state, or local law. Therefore, the exposure limit that must be complied with is 10 mrem per year (EDE) for the air pathway. Compliance is calculated for the nearest offsite receptor in an unrestricted area where any member of the public might be located. 


\subsubsection{Radiation Protection - Air Emissions (WAC 246-247)}

This regulation specifies new source review, notification, registration, and permitting requirements associated with any source of radioactive air emissions in Washington State, including those on the Hanford Site. One requirement listed in WAC 246-247 is the semiannual reporting of emissions from each registered stack or vent onsite. By agreement with Washington State Department of Health (WDOH), only annual reporting is required.

\subsubsection{Water Quality Standards for Groundwater (WAC 173-200)}

The water quality standards to protect groundwater to the level of drinking water standards are contained in Water Quality Standards for Groundwater of the State of Washington (WAC 173-200). These standards limit exposure to gross alpha, gross beta, tritium, strontium-90, radium-226, and -228 . For radionuclides that are not listed specifically, exposures are limited by the federal standard to an EDE not to exceed 4 mrem per year.

\subsubsection{State Waste Discharge Permit Program (WAC 173-216)}

The purpose of this regulation is to implement a state permit program, applicable to the discharge of waste materials from industrial operations into ground and surface waters of the state. However, this regulation excludes point source discharge of pollutants into navigable waters of the state, which is regulated by the National Pollutant Discharge Elimination System Permit Program (WAC 173-220): This regulation also excludes the injection of fluid through wells, which is regulated by Underground Injection Control Program (WAC 173-218).

\subsubsection{Dangerous Waste Regulations (WAC 173-303)}

Any release of a dangerous or hazardous substance (as designated by the WAC) to the environment, except permitted releases, must be reported. Waste streams that have the potential to contain dangerous waste constituents must be monitored accordingly.

\subsection{LOCAL REGULATIONS}

The local air pollution control authority, Benton Clean Air Authority (BCAA), has jurisdiction over open burning and asbestos handling in Benton County areas, including the Hanford Site.

\subsection{AIR EMISSIONS}

DOE Order 5400.5 provides requirements for the monitoring of radioactive and nonradioactive airborne effluents from DOE facilities on the Hanford Site. This order states that DOE-controlled facilities must comply with NESHAP (40 CFR 61, Subpart H).

Additional EPA requirements on hazardous substances are contained in CERCLA. This regulation provides information on reportable quantities of nonradioactive hazardous substances. Unlisted 
HNF-EP-0885 Rev. 1

hazardous substances designated by CERCLA are regulated in accordance with the EPA toxicity of the contaminant.

In Washington State, airborne effluents are regulated by the Washington State Department of Ecology through regulations in the WAC, 173-400 through 480, as amended, pursuant to the Washington Clean Air Act of 1967 (RAW 70.94, as amended). General regulations for air pollution sources are presented in WAC $173-400$, including emission standards for sources emitting hazardous air pollutants found in WAC 173-400-075.

WAC 246-247, Radiation Protection - Air Emissions, specifies new source review, notification, registration, and permitting requirements associated with any source of radioactive air emissions in Washington State, including those on the Hanford Site. By agreement with WDOH, only annual reporting is required.

WAC 173-480, Ambient Radionuclides, defines maximum allowable levels for radionuclides in the ambient air and defines required levels for control of emissions. WAC 173-480 lists an outdated dose standard of 25 mrem per year. However, the regulation contains a caveat stating that more stringent federal standards take precedence, therefore endorsing the 10 mrem per year EDE standard of NESHAP (40 CFR 61), Subpart H.

Regulations, including DOE Orders, state that DOE facilities must comply with the requirements set forth in NESHAP (40 CFR 61). Other regulations (e.g., 40 CFR 52, "Approval and Promulgation of Implementation Plans"; and DOE Orders 5400.1, 5400.5, 5484.1, and DOE/EH-0173T state that DOE facilities must comply with the applicable requirements set forth in the Washington Clean Air Act of 1967.

\subsection{LIQUID EFFLUENTS}

Depending on where a liquid effluent (wastewater) is discharged, certain regulations apply. These regulations are implemented through issuance of permits by federal, state, and/or local agencies. It is the responsibility of the facility, through DOE-RL, to apply for the permit appropriate to the effluent being discharged. Before applying for any permits, the applicant must know the source of wastewater discharges and where the wastewater is being discharged.

Each type of discharge permit identified typically contains discharge limitations and monitoring requirements. However, the limitations and monitoring requirements vary depending on the source and type of wastewater being discharged. Washington State controls discharges to groundwater and surface water of the state under WAC-173-216, State Waste Discharge Permit Program, and issues permits for such discharges. 
HNF-EP-0885 Rev. 1

This page intentionally left blank. 
Table 3-1. Applicable Regulations, Standards, and Permits

\begin{tabular}{|c|c|c|c|}
\hline Agency & Regulation, Standard, or Permit & $\begin{array}{l}\text { Applicable to } \\
\text { facility }\end{array}$ & Summary/Application \\
\hline \multirow{4}{*}{$\begin{array}{l}\text { U.S. Department } \\
\text { of Energy (DOE), } \\
\text { Washington, D.C. }\end{array}$} & DOE Order 5400.1 & $\bar{X}$ & $\begin{array}{l}\text { Provides general environmental } \\
\text { protection standards }\end{array}$ \\
\hline & $\begin{array}{l}\text { DOE Order } 5400.5 \\
(10 \text { CFR } 834 \text { if codified })\end{array}$ & $\bar{X}$ & $\begin{array}{l}\text { Sets radioactive release standards for the } \\
\text { public and environment (dose limits) }\end{array}$ \\
\hline & $\begin{array}{l}\text { DOE Order } 5820.2 \mathrm{~A} \\
\text { (10 CFR } 835 \text { applicable also) }\end{array}$ & $\bar{X}$ & $\begin{array}{l}\text { Sets radioactive waste management } \\
\text { requirements ( } 10 \text { CFR } 835 \text { requires } \\
\text { monitoring for outdoor contamination } \\
\text { near facility) }\end{array}$ \\
\hline & $\begin{array}{l}\text { DOE/EH-0173T } \\
\text { Environmental Regulatory Guide } \\
\text { for Radiological Effluent } \\
\text { Monitoring and Environmental } \\
\text { Surveillance }\end{array}$ & $\bar{X}$ & $\begin{array}{l}\text { Provides guidance for effluent sampling } \\
\text { and monitoring }\end{array}$ \\
\hline \multirow{6}{*}{$\begin{array}{l}\text { U.S. } \\
\text { Environmental } \\
\text { Protection } \\
\text { Agency (EPA), } \\
\text { Washington, D.C. }\end{array}$} & $\begin{array}{l}40 \text { CFR } 60 \\
\text { Standards of Performance for New } \\
\text { Stationary Sources }\end{array}$ & $\overline{\mathrm{X}}$ & $\begin{array}{l}\text { Establishes monitoring requirements for } \\
\text { air pollutants }\end{array}$ \\
\hline & $\begin{array}{l}40 \text { CFR } 61 \\
\text { NESHAP }\end{array}$ & $\bar{X}$ & $\begin{array}{l}\text { Sets national emission standards for } \\
\text { hazardous air pollutants (NESHAP) }\end{array}$ \\
\hline & $\begin{array}{l}40 \text { CFR 61, Subpart H } \\
\text { NESHAP for Radionuclides other } \\
\text { than Radon from Department of } \\
\text { Energy Facilities }\end{array}$ & $\bar{X}$ & $\begin{array}{l}\text { Sets emissions standards/monitoring } \\
\text { requirements for radionuclides }\end{array}$ \\
\hline & $\begin{array}{l}40 \text { CFR } 70 \\
\text { State Operating Permit Program }\end{array}$ & $\bar{X}$ & $\begin{array}{l}\text { Requires state air operating permit } \\
\text { programs (i.e., WAC 173-401) }\end{array}$ \\
\hline & $\begin{array}{l}40 \text { CFR } 261 \\
\text { Identification and Listing of } \\
\text { Hazardous Waste }\end{array}$ & $\bar{X}$ & Identifies and lists hazardous waste \\
\hline & $\begin{array}{l}40 \text { CFR } 302 \\
\text { Designation, Reportable Quantities, } \\
\text { and Notification }\end{array}$ & $\bar{X}$ & $\begin{array}{l}\text { Identifies the allowable release limits of } \\
\text { hazardous and radioactive constituents }\end{array}$ \\
\hline \multirow[t]{2}{*}{$\begin{array}{l}\text { American } \\
\text { National } \\
\text { Standards } \\
\text { Institute (ANSI) }\end{array}$} & $\begin{array}{l}\text { ANSI N 13.1* } \\
\text { Guidance to Sampling Airborne } \\
\text { Radioactive Materials in Nuclear } \\
\text { Facilities }\end{array}$ & $\mathrm{X}$ & $\begin{array}{l}\text { Sets standards for effluent monitoring } \\
\text { systems }\end{array}$ \\
\hline & $\begin{array}{l}\text { N } 42.18^{*} \text { Specification and } \\
\text { Performance of On-Site } \\
\text { Instrumentation for Continuously } \\
\text { Monitoring Radioactivity in } \\
\text { Effluents }\end{array}$ & $\overline{\mathrm{X}}$ & $\begin{array}{l}\text { Recommendations for the selection of } \\
\text { instrumentation for the monitoring of } \\
\text { radioactive effluents }\end{array}$ \\
\hline
\end{tabular}


Table 3-1. Applicable Regulations, Standards, and Permits

\begin{tabular}{|c|c|c|c|}
\hline Agency & Regulation, Standard, or Permit & $\begin{array}{l}\text { Applicable to } \\
\text { facility }\end{array}$ & Summary/Application \\
\hline \multirow{4}{*}{$\begin{array}{l}\text { Washington State } \\
\text { Department of } \\
\text { Ecology } \\
\text { (Ecology), } \\
\text { Olympia, WA }\end{array}$} & $\begin{array}{l}\text { WAC } 173-216 \\
\text { State Waste Discharge Permit } \\
\text { Program }\end{array}$ & $\mathrm{N} / \mathrm{A}$ & $\begin{array}{l}\text { Governs discharges to ground and } \\
\text { surface waters }\end{array}$ \\
\hline & $\begin{array}{l}\text { WAC } 173-220 \\
\text { National Pollutant Discharge } \\
\text { Elimination System Permit }\end{array}$ & $\mathrm{N} / \mathrm{A}$ & $\begin{array}{l}\text { Governs wastewater discharges to } \\
\text { navigable waterways; controls NPDES } \\
\text { permit process }\end{array}$ \\
\hline & $\begin{array}{l}\text { WAC 173-303 } \\
\text { Dangerous Waste Regulations }\end{array}$ & $\overline{\mathrm{X}}$ & $\begin{array}{l}\text { Regulates dangerous wastes; prohibits } \\
\text { direct release to soil columns }\end{array}$ \\
\hline & $\begin{array}{l}\text { WAC 173-400 } \\
\text { General Regulations for Air } \\
\text { Pollution Sources }\end{array}$ & $\mathrm{X}$ & $\begin{array}{l}\text { Sets emissions standards for hazardous } \\
\text { air pollutants }\end{array}$ \\
\hline \multirow{4}{*}{$\begin{array}{l}\text { Washington State } \\
\text { Department of } \\
\text { Health (WDOH), } \\
\text { Olympia, WA }\end{array}$} & $\begin{array}{l}\text { WAC 246-247 } \\
\text { Radiation Protection - Air } \\
\text { Emissions }\end{array}$ & $\mathrm{X}$ & $\begin{array}{l}\text { Sets standards for registration, } \\
\text { permitting, notification, new sources, } \\
\text { review, monitoring, and reports }\end{array}$ \\
\hline & Notice of Construction & $\bar{X}$ & If applicable. \\
\hline & $\begin{array}{l}\text { FF-01 Radioactive Airborne } \\
\text { Emissions }\end{array}$ & $\bar{X}$ & $\begin{array}{l}\text { Collective emissions from registered } \\
\text { sources must meet the emissions } \\
\text { requirements of WAC } 173-480 .\end{array}$ \\
\hline & Regulation 1 & $\bar{X}$ & $\begin{array}{l}\text { Regulates air quality regarding. } \\
\text { compliance with } 40 \text { CFR } 61 \text {,Subpart M } \\
\text { for asbestos and open burning. }\end{array}$ \\
\hline
\end{tabular}

$\mathrm{N} / \mathrm{A}=$ not applicable

* Referenced in DOE and EPA regulations. 
HNF-EP-0885 Rev. 1

\subsection{IDENTIFICATION AND CHARACTERIZATION OF EFFLUENT STREAMS}

This section discusses source terms (radiological and nonradiological) for WRAP that need to be considered potential contributors to public exposures and evaluated against instrumentation design criteria. Both routine operational conditions and hypothetical upset conditions are presented.

WRAP has both gaseous and liquid effluent streams. According to the FEMP determination, the air effluent stream has the potential to exceed the radioactive emissions set by NESHAP ( 40 CFR 61). The liquid effluent streams are identified, but do not exceed nor have the potential to exceed the radioactive and regulated material criteria identified by applicable regulations. These descriptions include an identification of the potential source terms contributing to each stream.

\subsection{IDENTIFICATION AND CHARACTERIZATION OF SOURCE TERMS CONTRIBUTING TO EACH EFFLUENT STREAM}

This section describes the source terms that contribute to the WRAP effluent streams during routine or upset operating conditions. General information on the effluent streams is presented in Table 4-1.

\subsubsection{Routine Operating Conditions}

During normal operating conditions, the only effluent stream that has the potential to exceed either the radioactive or hazardous material emission limits is the main stack. This is the only exhausting point for the process area (Zone II) and the process gloveboxes (Zone I). The shipping and receiving area, material assay area, storage area, some material transport routes, and administrative areas are considered part of the Zone III exhaust system. There is a negative pressure gradient from Zone II to Zone I to provide maximum confinement of radioactive contamination. Zones I and II use a once-through, pushpull-type ventilation system.

The glovebox lines in which the radioactive materials are processed are considered Zone I ventilation areas. Zone I obtains inlet air from the room in which the gloveboxes are located, which is considered Zone II. Zone I and Zone II exhausts are each ducted to their own high-efficiency particulate air (HEPA) filtration banks; each bank consisting of two stages of HEPA filters before being combined and subsequently discharged to the atmosphere. Zone I and Zone II each have two banks of HEPA filters, with one serving as backup to the other. During routine maintenance activities (e.g., filter changeout) or if an equipment component fails, the exhaust flow is diverted to the backup filter bank.

Use of particulate control measures, as described previously, allows for high-efficiency removal of particulates and provides system redundancy for a possible failure of one of the emission control units. In addition, the gloveboxes are equipped with non-testable HEPA filters on both the inlet and outlet flows to minimize the radionuclide contamination of the exhaust ducts and final filter banks.

High-efficiency particulate filtration before discharge of the radionuclide contaminated air to the atmosphere is a nuclear industry standard and is determined as best available radionuclide control technology (BARCT) and toxic best available control technology (TBACT) for particulates. HEPAs are disposable, extended-medium, dry filters with a rigid casing enclosing the full depth of the pleats. HEPAs have a particle removal efficiency range of 99.95 percent to 99.99 percent for 0.3 micron thermally-generated, monodispersed polyalphaolefin test aerosol particles, and a maximum pressure drop of 1 inch of water column when clean and operated at rated airflow capacity. The core of a HEPA filter 
generally is made by pleating a continuous web of fiberglass paper back and forth over corrugated separators that add strength to the core and provide air passages between the pleats. The core is sealed in a wood or metal casing. The filter paper itself is composed of very fine (i.e., submicron) glass fibers in a matrix of larger (i.e., 1 to 4 microns) fibers and held together with an organic binder.

Hazardous materials that might be released in the stack emissions fall well short of exceeding the reportable quantities for a 24-hour period. This can be seen in Section 2.0, Table 2-2. In Section 2.0, Table 2-1 identifies that the radioactive emissions from the stack have the potential to exceed the 0.1 mrem per year EDE limit identified for single facilities. The method used to calculate the EDE for WRAP was based on 40 CFR 61, Appendix D, methodology. This is an extremely conservative method; however, it is the best available method to anticipate radionuclide quantities given a partially characterized feed stream.

\subsubsection{Upset Operating Condition}

In the case of an upset condition, WRAP would not release material listed in the 40 CFR 302.4 table of hazardous substances in quantities equaling or exceeding the RQ amount for any 24-hour period. Given the primarily solid nature of the waste processed in WRAP, the release of radionuclides during an upset condition would not exceed emission estimates given in Section 2.0, Table 2-1. 
HNF-EP-0885 Rev. 1

Table 4-1. Waste Receiving and Processing Facility Gaseous and Liquid Effluent Streams.

\begin{tabular}{|l|l|l|l|l|l|}
\hline \multicolumn{1}{|c|}{ Stream } & $\begin{array}{c}\text { Discharge } \\
\text { designation }\end{array}$ & \multicolumn{1}{|c|}{$\begin{array}{c}\text { Effluent } \\
\text { description }\end{array}$} & $\begin{array}{l}\text { Hazardous } \\
\text { chemical } \\
\text { content }\end{array}$ & $\begin{array}{c}\text { Radioactive } \\
\text { material } \\
\text { content }\end{array}$ & \multicolumn{1}{|c|}{ Comments } \\
\hline Air effluent & $\begin{array}{l}\text { Main Stack } \\
296-\text { W-004 }\end{array}$ & $\begin{array}{l}\text { Main filtered } \\
\text { exhaust effluent } \\
\text { discharge }\end{array}$ & $\begin{array}{l}\text { Reference } \\
\text { Section 2.0, } \\
\text { Table 2-2 }\end{array}$ & $\begin{array}{l}\text { Reference } \\
\text { Section 2.0, } \\
\text { Table 2-1 }\end{array}$ & $\begin{array}{l}\text { Low radioactive } \\
\text { potential }\end{array}$ \\
\hline $\begin{array}{l}\text { Liquid } \\
\text { effluent }\end{array}$ & $\begin{array}{l}\text { Miscellaneous } \\
\text { Stream \#424 }\end{array}$ & $\begin{array}{l}\text { TRUPACT } \\
\text { unload bay drain }\end{array}$ & $\begin{array}{l}\text { No hazards } \\
\text { exceeding RQ } \\
\text { values }\end{array}$ & None & None \\
\hline $\begin{array}{l}\text { Liquid } \\
\text { effluent }\end{array}$ & $\begin{array}{l}\text { Miscellaneous. } \\
\text { Stream \#407 }\end{array}$ & $\begin{array}{l}\text { Compressor } \\
\text { condensate } \\
\text { discharge }\end{array}$ & $\begin{array}{l}\text { No hazards } \\
\text { exceeding RQ } \\
\text { values }\end{array}$ & None & $\begin{array}{l}\text { Oil/water separator } \\
\text { pass before } \\
\text { discharge }\end{array}$ \\
\hline
\end{tabular}

$\mathrm{RQ}=$ reportable quantity.

TRUPACT $=$ transuranic package transporter. 
HNF-EP-0885 Rev. 1

This page intentionally left blank. 
HNF-EP-0885 Rev. 1

\subsection{EFFLUENT POINT OF DISCHARGE DESCRIPTION}

This section characterizes the effluent discharge points within WRAP. This characterization includes the identification of all contributing streams, physical dimensions, monitoring system location, flow rates, and other pertinent information.

\subsection{MAIN STACK}

The WRAP main stack exhausts HEPA filtered process and ventilation air from the Zone I and Zone II areas. The areas that contribute to these zones include the LLW and TRU processing gloveboxes, and the LLW and TRU waste RWM gloveboxes. Because the Zone III areas provide the makeup air for the Zone II area, Zone III areas indirectly contribute to the total air effluent stream. The Zone I area is filtered through a HEPA filtration system that consists of two stages and a pre-filter. There is an identical bank in parallel with the first that can be used in case of failure or HEPA change out. Zone II exhaust is routed through a separate two-stage HEPA filtration system with back up. The Zone I and Zone II streams are joined after filtration, and exhausted through the stack. Figure 5-1 presents the overall piping schematic for the filtration and exhaust system.

The 14-meter fabricated steel stack (ID $\# 296-$ W-004) is located at the northwest corner of the building. The stack has a diameter of 0.81 meter, with isokinetic sampling and monitoring probes located approximately 11.3 meters from the base of the stack. The sample is transported through tubing to a monitoring cabinet located on the inside of the northwest corner of the building. The cabinet contains a record sampler, an alpha/beta continuous air monitor, and associated flow and temperature measuring instrumentation. The monitoring cabinet is equipped with local annunciator alarms, as well as interface capabilities with the plant control system (PCS) alarms. The record sampler uses a 47 millimeter diameter media size filter for particle collection distribution. Because the sampling and monitoring equipment is housed in a cabinet and located within WRAP, equipment is not exposed to any harsh environmental conditions.

The isokinetic probe assembly consists of a multi-point velocity probe, temperature probe, and three independent, low-particle loss, multi-point nozzle arrays for particulate sample collection. The probe assemblies are mounted by direct insertion into the stack mounting flange. All of the sample transport tubing changes in direction have radii curvatures greater than 5 tube diameters. Table 5-1 presents pertinent sampling and monitoring technical data design.

\subsection{LIQUID EFFLUENT DISCHARGE LOCATION}

Liquid effluent discharge locations are discussed in the following sections.

\subsubsection{TRUPACT Bay Drain Basin}

WRAP is equipped with a TRUPACT loading and unloading bay with a full length floor drain. The principal purpose for the drain is to divert the melting snow and ice collected on transport vehicles to a proper disposal location. The drain also serves as an authorization basis safety function to remove leaking fuel from the loading bay in the event a transport fuel tank rupture. The floor drain runs out of the east side of the building to a 2,650-liter sand interceptor. If the sand interceptor ever reaches capacity, the liquid stream could overflow and discharge to a gravel basin located approximately 
100 meters from the east side of the building. This is a discharge method accepted by Ecology, provided the drain basin is wider than it is deep; which is the case for WRAP. This liquid stream is subject to the requirements of State Waste Discharge Permits ST 4508, ST 4509, and ST 4510.

\subsubsection{Compressor Condensate Drain Basin}

WRAP has a mechanical room that houses two compressors, an air dryer, several pumps, and a domestic water heater. The condensate that builds up in the compressor is combined with the air dryer condensate and discharged to a gravel basin on the north side of the building. The ventilation air inlet equipment also drains to the compressed air and air drier drain system. The condensate passes through an oil/water separator before discharge to the environment to isolate the oil blow-through that usually occurs in compressors. The dimensions of the gravel basin are 1.5 meters wide by 1.5 meters long by 0.5 meter deep. The compressor condensate discharge stream has been added to the Hanford Site Plan and Schedule for Disposition and Regulatory Compliance for Miscellaneous Streams, (DOE/RL-93-18) as well as listed in the site inventory of miscellaneous streams (e.g., DOE/RL-95-85). This liquid stream is subject to the requirements of the State Waste Discharge Permits ST 4508, ST 4509, and ST 4510. 


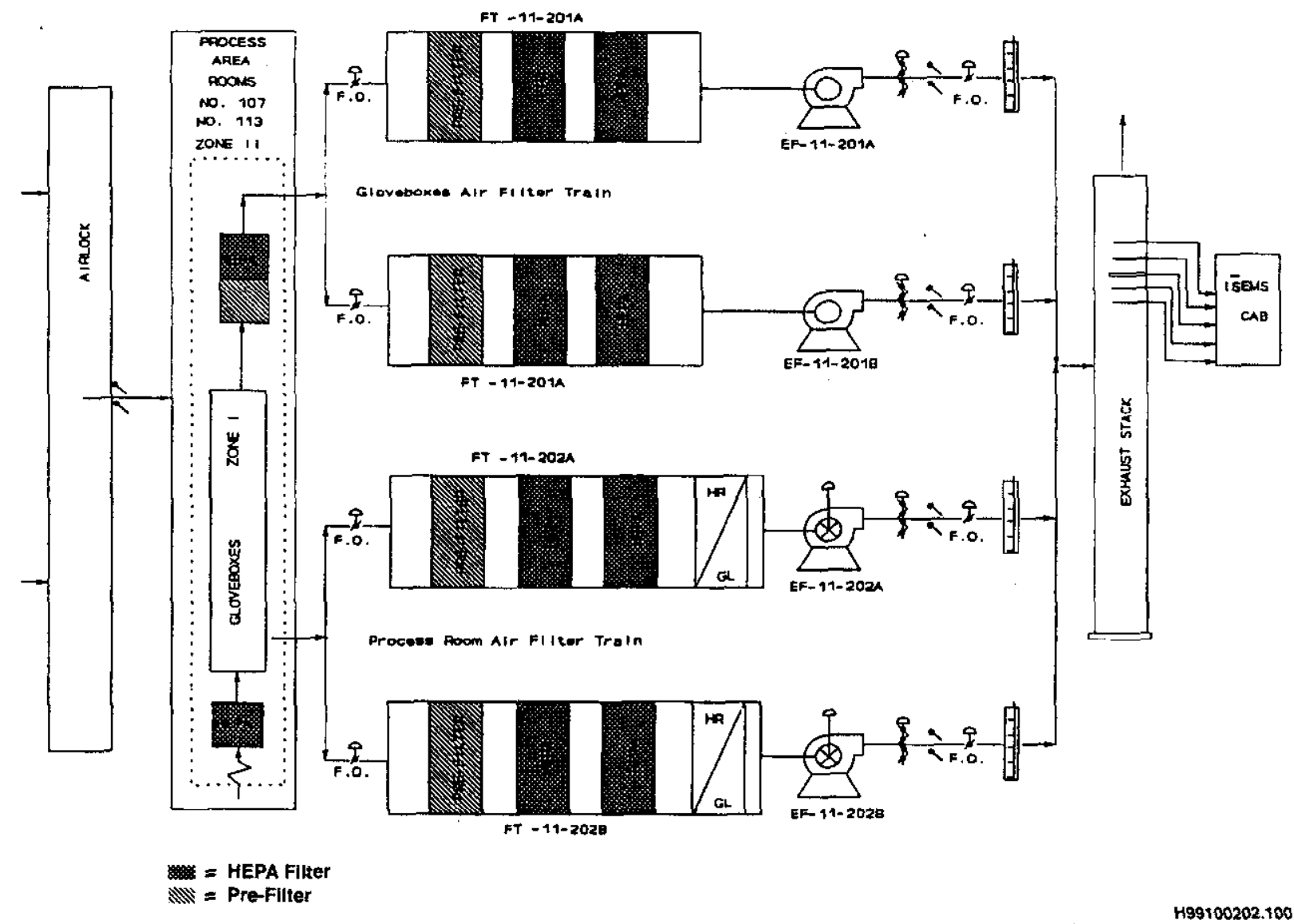

Figure 5-1. Gaseous Effluent Flow Diagram. 
HNF-EP-0885 Rev. 1

This page intentionally left blank. 
HNF-EP-0885 Rev. 1

Table 5-1. Technical Design Data for the Waste Receiving and Processing Facility Exhaust Stack.

\begin{tabular}{|l|l|l|}
\hline \multicolumn{1}{|c|}{ Technical data } & \multicolumn{1}{|c|}{ Designed } & \multicolumn{1}{|c|}{ Measured } \\
\hline Average flow rate & 463.83 cubic meters per minute & 459.30 cubic meters per minute \\
\hline Minimum flow rate & 28.317 cubic meters per minute & 28.317 cubic meters per minute \\
\hline $\begin{array}{l}\text { Maximum flow rate } \\
\text { Ambient stack air } \\
\text { temperature }\end{array}$ & 510.27 cubic meters per minute & 507.72 cubic meters per minute \\
\hline
\end{tabular}


HNF-EP-0885 Rev. 1

This page intentionally left blank. 
HNF-EP-0885 Rev. 1

\subsection{EFFLUENT MONITORING/SAMPLING SYSTEM DESIGN CRITERIA}

This section presents the design criteria for the gaseous effluent monitoring system within WRAP. The liquid effluents streams do not require permanent monitoring. The air effluent sampling and monitoring are based on design criteria found in 40 CFR 60, Appendix A; 40 CFR 61, Subpart H; 40 CFR 61, Appendix B; DOE/EP-0096; DOE/EH-0173T; and ANSI N13.1.

\subsection{AIRBORNE EFFLUENTS}

NESHAP establishes requirements and procedures for measuring radionuclide emissions from point sources. The requirements are contained in 40 CFR 61.93. The following sections present methods that NESHAP mandates for an airborne radionuclide effluent monitoring system. The essential requirements for design and operation of an airborne effluent release monitoring system mandated by NESHAP for DOE facilities are as follows.

- Effluent flow rate must be measured using EPA Method 2 in large stacks and vents or EPA Method 2A in pipes and small vents (40 CFR 60, Appendix A).

- Radionuclides will be directly monitored or extracted, collected, and measured.

- The placement of the sampling/monitoring probes must be derived using EPA Method I (40 CFR 60, Appendix A).

- If the measurement is not performed in situ, the guidance in ANSI N13.1 must be followed for sample extraction.

- Radionuclides must be measured according to 40 CFR 61, Appendix B, Method 114.

- A QA program must be conducted that meets the performance requirements described in 40 CFR 61 , Appendix B, Method 114.

\subsubsection{Measurement of Effluent Flow Rate}

NESHAP requires that flow rate measurements be made of the gaseous effluent stream as the stream exits the stack. The flow rate is useful in deriving total emission rates from the concentration or activity levels measured in the extracted samples. EPA Method 2 (40 CFR 60, Appendix A) is specified by NESHAP to determine velocity and volumetric flow rates for stacks.

\subsubsection{Sample Extraction Probes}

The sample extraction probes are designed for representative isokinetic sample extraction based on the average stack velocity. NESHAP requires that ANSI N13.1 be used as the standard guideline for the design of an effluent monitoring system. The standard encompasses the design and location of the probes as well as the transport system for moving the sample from the orifice of the probe to the sample collection device or analyzer. ANSI N13.1 guidelines are designed to ensure that the sample that is collected and/or measured gives a good representative sample of the effluent stream at the point of extraction. Several factors can affect the sample representation during the collection and transport 
processes. These include inertial separation, deposition sample loss/dilution, and physical or chemical changes. ANSI N13.1 provides the following guidance for mitigating the impact of these factors.

- NESHAP requires that ANSI N13.1, Appendix A, be used for sample probe location in the stack. This requires the sample probes to be located a minimum of 5-duct diameters down stream.

- Independent sample extraction probes are required to be provided for the record sample loop and the continuous air monitor loops. However, a Hanford Site approved flow splitter can be used to divert one stream to the record sampler and continuous air monitor (CAM).

- ANSI N13.1 recommends that sampling lines be avoided whenever possible and always kept at a minimum length so as to prevent deposition losses of heavy particles.

- Sample extraction probes are to be flange mounted to the stack to facilitate periodic removal, inspection, and cleaning activities.

\subsubsection{Sample Transport Lines}

Sample transport lines are to be installed in a manner that minimizes particle loss attributed to gravity settling, turbulent impaction, and electrostatic effects. This requires bends and lengthy runs of sample lines be kept to a minimum. ANSI N13.1 requires the line bend radii to be at least five times greater than the inside diameter of the transport line.

\subsubsection{Record Sampling}

The record sample air stream is routed through a 47-millimeter filter media to obtain a collective sample of the effluent stream for laboratory analysis. Sample flow rate, indicating and totalizing capabilities, along with a flow rate regulator are include in the record sampling system. The flow rate regulator compensates for filter loading effects and maintain a constant sampling flow rate.

\subsection{CONTINUOUS AIR MONITORS}

Each CAM is supplied a representative sample of the effluent stream by regulating the sample line flow rate. The CAM alarm setpoints are adjusted to activate at release concentrations as low as possible without resulting in an excessive number of alarms because of normal fluctuations in background radiation. CAM failure annunciation is provided and the CAM system is checked periodically to verify system response. 
HNF-EP-0885 Rev. 1

\subsection{CHARACTERIZATION OF CURRENT EFFLUENT MONITORING SYSTEM}

This section provides a description of the effluent monitoring system and the technical specifications related to the WRAP effluent stack.

\subsection{INSTRUMENTATION DESCRIPTION}

The gaseous effluent monitoring/sampling system operates isokinetically. The stack has sample probes that divert a representative sample of the exhaust stream via transport tubing to the sampling and monitoring cabinet. The transport lines are heat traced to prevent condensation within the tubing. A continuous sampler collects a record sample for laboratory analysis and CAMs monitor the exhaust for alpha and beta emissions. The stack also houses a temperature probe and a velocity probe. The flow through the systems is established and maintained by vacuum pumps, and measured by flow measuring sensors. A brief discussion and specification listing of the monitoring system instrumentation is given in the following sections.

The isokinetic probe assembly consists of a multi-point velocity probe, temperature probe, and two independent, low-particle loss, multi-point nozzle arrays for particulate collection. The probe assemblies are mounted by direct insertion into the stack mounting flange.

\subsubsection{Probe Mounting Features}

There are two stack sampling points, one for alpha/beta monitoring and one for record sampling. The sampling points are positioned and designed in accordance with 40 CFR 61.93.

The sampling probe assemblies are located at least five stack diameters downstream from any flow perturbation, and two stack diameters from the top of the stack. The actual locations are six and three.

The complete probe assembly is mounted perpendicular to the stack air flow by a mounting flange.

- The individual probes are coupled to the mounting flange.

- Each probe assembly is offset so as not to interrupt the air flow to any of the other flanges.

- Each probe array has thread-on sampling nozzles spaced evenly and symmetrically on the assembly, which has been accepted as an alternative to ANSI N13.1.

The probe assemblies and all associated transport tubing are fabricated from type 316 stainless steel.

\subsubsection{Sample Probes}

Each nozzle orifice is tapered according to ANSI N13.1 and faces directly into the exhaust stream.

The sample nozzles are sized to extract samples at the same velocity as the effluent stream (hence isokinetic) when the particle aerodynamic equivalent diameter (AED) exceeds 0.5 micron. 
Each sample probe is designed to deliver a representative sample of the exhaust stream having a loss of less than $25 \%$ for a 5.0 micron AED particle and $60 \%$ for a 15 micron AED particle. This is in accordance with.ANSI N13.1.

\subsubsection{Velocity Probe}

The velocity probe is offset from the sample probes to prevent flow disturbances and adverse affects in the flow readings.

The multi-point velocity probe measures the flow rate of the exhaust stream. Velocity sensor specifications are as follows.

- No more than $+/-2.0 \%$ error for velocity direction for velocity direction deviation angles of $+/-15.0$ percent in either yaw or rotational axis.

- Each flow sensor is rated for an accuracy within $+/-2.0 \%$ for readings and an accuracy within $+/-0.5$ percent of full scale of the site conditions.

- The total stack flow accuracy is with in $+/-10$ percent for the normal operating range of approximately 465 cubic meters per minute, and within $+/ .25$ percent of the minimum flow rate or 28 cubic meters per minute.

\subsubsection{Temperature Probe}

The stack air temperature probe supplies the set point to the sample line heat trace controllers to maintain the sample lines at the stack temperature.

\subsubsection{Record Sample Collectors}

The filter assembly is located in the isokinetic stack effluent monitoring system cabinet. The cabinet is located in a climate controlled area and not susceptible to adverse atmospheric conditions. The collection site is located as close as practical to the sample points so as to minimize the amount of particle loss in the transport tubing.

Filter assembly characteristics are as follows.

- A standard 47-millimeter diameter media size filter is used fọr particle collection.

- A compression ring is used to ensure a tight seal against the support backing.

- The filter assemblies have tapered expansion and contraction cones both upstream and downstream to ensure even particle distribution.

\subsubsection{Sample Transport Tubing}

The sample transport tubing is fabricated from type 316 stainless steel. To aid in the prevention of particle plate out, the minimum possible lengths of tubing are used and any direction change in the 
transport tubing is made with radii curvatures greater than five tube diameters. The overall bend radius does not exceed 90 degrees as per ANSI N13.1.

Easily accessible calibration taps are located in the sample lines to allow in-place verification of the sample line flow rate.

\subsubsection{Continuous Air Monitor}

The CAM is alpha/beta aerosol monitor, located in the isokinetic stack effluent monitoring system cabinet and measures the radioactive particulate concentrations in the exhaust streams. The CAM counts using a pseudocoincidence utility that allows for radon and natural occurring background radiation discrimination.

\subsection{TECHNICAL SPECIFICATIONS PERTAINING TO THE EFFLUENT MONITORING}

WRAP personnel continually monitor the air effluents exhausted from Zone I and Zone II areas through the main stack. Hazardous air pollutants other than radionuclides are not sampled or monitored. Stack emissions tests will be performed for volatile organic carbons (VOC) after start up. DOE-RL will submit a test plan to Ecology at least 45 days before testing. In an agreement with Ecology, testing is to occur after the start of processing waste from the Transuranic Waste-Retrieval Project (Ecology requests notification at least 14 days before to the initial processing of the retrieved waste.). After these tests, annual tests could be required. Because the potential radioactive emissions could cause an EDE of greater than 0.1 mrem per year to the MEI at WRAP, continuous monitoring and sampling of radionuclide emissions are required. 


\section{HNF-EP-0885 Rev. 1}

This page intentionally left blank. 
HNF-EP-0885 Rev. 1

\subsection{HISTORICAL MONITORING/SAMPLING DATA FOR EFFLUENT STREAMS}

Historical air effluent monitoring and sampling data have been assembled in annual reports (DOE/RL-99-41). These reports typically recorded the routine releases, unusual occurrences (i.e., upset conditions), sample points, analytical data sheets, instrument calibration records, and other information. 
HNF-EP-0885 Rev. 1

This page intentionally left blank. 


\subsection{SAMPLE ANALYSIS}

Sample analysis, tracking, and analytical procedures are discussed in the following sections.

\subsection{ANALYTICAL LABORATORY PROCEDURES}

The analytical and laboratory procedures for FEMP activities are identified in quality assurance project plans (QAPjP), one quality assurance program plan (QAPP), and the annual statement of work as follows:

- WHC-EP-0446-2, Quality Assurance Project Plan for the Facility Effluent Monitoring Plan Activities

- HNF-EP-0528-3, NESHAP Quality Assurance Project Plan for Radioactive Airborne Emissions

- HNF-EP-0835-5, Statement of Work for Services Provided by the Waste Sampling and Characterization Facility for the Effluent and Environmental Program during Calendar Year 1999.

\subsubsection{Record Sample Exchange}

Sample identification is initiated by the operations group taking the sample. Sampling personnel use the Automated Bar Coding of Air Samples at Hanford (ABCASH) system to provide sample identification and chain of custody, which is performed through ABCASH electronically. Sample custody is transferred when the analytical laboratory receives the properly marked sample.

A health physics technician performs the sample exchanges in the air sampling and monitoring devices. Tracking of radioactive airborne emissions sample data is controlled through assignment of unique electronic processing codes for each sample location. Codes are used by laboratory personnel to report the results in accordance with the QAPjP for radioactive emissions data.

\subsubsection{Continuous Air Monitor Filter Exchange}

CAM filters are exchanged per WRAP specific methods.

\subsubsection{Sample Data Examination and Delivery}

Sample data examination and delivery to an analytical laboratory are conducted per HNF-PRO-2364, "Radioactive Airborne Effluent Sampling".

\subsubsection{Laboratory Sample Analysis Instructions}

An EDP code is assigned to each discharge point monitoring and sampling equipment units. The minimum detectable concentrations are specified in Table 9-1. 
When the sample reaches the laboratory, the 'record' sample is held in the laboratory for 7 days to allow the short-lived natural occurring isotopes to decay. The sample is counted for alpha and beta readings. These samples are put in storage for further sampling. Quarterly, these samples are gathered and dissolved for radioanalysis. The results of these analyses are submitted and reported annually.

The CAM samples are not treated as record samples unless specifically requested. CAM filters from the stacks are managed by an onsite radiological control group.

\subsection{SAMPLE DATA AND TRACKING}

Tracking of radioactive airborne emissions sample data is controlled through assignment of unique EDP codes for each sample location. The EDP codes are used by the Waste Sampling and Characterization Facility to report the results in accordance with the QAPjP for radioactive emissions data.

\subsection{U.S. DEPARTMENT OF ENERGY ANALYTICAL AND LABORATORY GUIDELINES}

The analytical and laboratory procedures for the radionuclide air emissions are identified in HNF-EP-0528. General requirements for laboratory procedures, data analyses, and statistical treatment are addressed (Table 9-2).

The following elements identified in DOE/EH-0173T are addressed in Quality Assurance Program Plan for Laboratory Analysis and Process Testing, (HNF-SD-CP-QAPP-017):

- Procedures preventing cross contamination

- Documentation of methods

- Calibration

- Handling of samples

- Analysis method and capabilities

- Gross alpha, beta, and gamma measurements

- Direct gamma-ray spectrometry

- Beta counters

- Alpha-energy analysis

- Radiochemical separation procedures

- Reporting of results

- Counter calibration

- Inter-calibration of equipment and procedures

- Counter background

- Quality assurance. 
Table 9-1. Minimum Detectable Concentrations for Specific Radionuclides as Measured in Air Samples.

\begin{tabular}{|c|c|}
\hline Radionuclide & $\begin{array}{c}\text { Minimum quantifiable concentration } \\
(\mu \mathrm{Ci} / \mathrm{mL})\end{array}$ \\
\hline Total alpha & $2.0 \mathrm{E}-15$ \\
\hline Total beta & $1.9 \mathrm{E}-14$ \\
\hline $\begin{array}{c}\text { Gamma energy analysis of } \mathrm{Ag} \\
\text { Zeolite }(\mathrm{Ru}-106)\end{array}$ & $3.4 \mathrm{E}-13$ \\
\hline${ }^{239.240} \mathrm{Pu}$ & $2.0 \mathrm{E}-15$ \\
\hline${ }^{238} \mathrm{Pu}$ & $2.0 \mathrm{E}-15$ \\
\hline${ }^{241} \mathrm{Am}$ & $1.9 \mathrm{E}-15$ \\
\hline${ }^{90} \mathrm{Sr}$ & $1.9 \mathrm{E}-14$ \\
\hline${ }^{106} \mathrm{RulRh}$ & $3.4 \mathrm{E}-13$ \\
\hline
\end{tabular}

$\mu \mathrm{Ci} / \mathrm{mL}=$ microcuries per milliliter. 
HNF-EP-0885 Rev. 1

Table 9-2. Data Analyses and Statistical Treatment.

\begin{tabular}{|l|l|}
\hline \multicolumn{1}{|c|}{ Element } & \multicolumn{1}{|c|}{ Documentation } \\
\hline $\begin{array}{l}\text { Summary of data and statistical treatment } \\
\text { requirements }\end{array}$ & HNF-SD-CP-QAPP-017, Rev. 3 \\
\hline $\begin{array}{l}\text { Variability of effluent and environmental } \\
\text { data }\end{array}$ & HNF-EP-0527-8 \\
\hline $\begin{array}{l}\text { Summarization of data and testing for } \\
\text { outliers }\end{array}$ & $\begin{array}{l}\text { Statistical identification of control standards is performed } \\
\text { by the laboratory measurement control system database } \\
\text { program during the annual review of data for setting } \\
\text { control limits. Outliers are evaluated. }\end{array}$ \\
\hline Treatment of significant figures & HNF-SD-CP-QAPP-017, Rev. 3 \\
\hline Parent-decay product relationships & $\begin{array}{l}\text { Parent-decay product relationships are not accounted for } \\
\text { in laboratory operating procedures. }\end{array}$ \\
\hline $\begin{array}{l}\text { Comparisons to regulatory or administrative } \\
\text { control standards and control data }\end{array}$ & WSCF participates in the EPA Inter-Comparison Program \\
\hline Quality assurance & HNF-SD-CP-QAPP-017, Rev. 3 \\
\hline
\end{tabular}


HNF-EP-0885 Rev. 1

\subsection{NOTIFICATIONS AND REPORTING REQUIREMENTS}

Notification and reporting requirements are imposed by federal and state laws as well as by DOE Orders. This section serves as a guideline for general notification and reporting requirements and as a reference to the sources where specific information can be found for federal, state, and DOE requirements.

\subsection{ENVIRONMENTAL OCCURRENCE}

Notifications and reporting of specific events related to environmental releases and/or events involving effluents and/or hazardous materials are made in accordance with DOE Orders 5400.1, 5484.1, and 232.1 .

\subsection{PERIODIC ROUTINE EFFLUENT MONITORING REPORTS}

Annual effluent monitoring data are compiled and reported in several annual reports (e.g., DOE/RL-99-41). 
HNF-EP-0885 Rev. 1

This page intentionally left blank. 


\subsection{INTERFACE WITH NEAR-FACILITY MONITORING}

The sitewide Environmental Monitoring Plan (EMP), DOE/RL-91-50, consists of two distinct but related components: environmental surveillance conducted by PNNL and effluent monitoring conducted by FH. Environmental surveillance, conducted by PNNL, consists of surveillance of all environmental parameters to demonstrate compliance with regulations. Effluent monitoring includes in-line and facility effluent monitoring as well as near-facility environmental monitoring. Projected offsite doses, reported in this FEMP, are the products of effluent monitoring and source term evaluation. Near-field monitoring (NFM) is required in accordance with procedures described in the operational environmental monitoring QAPjP.

\subsection{PURPOSE}

NFM provides facility-specific environmental monitoring to protect the environment adjacent to facilities under the responsibility of $\mathrm{FH}$ and to ensure compliance with federal, state, and local environmental regulations.

The objectives of the NFM are to evaluate the following:

- Compliance with DOE, EPA, Ecology, WDOH, and FH environmental radiation protection requirements and guides

- Performance of radioactive waste confinement systems

- Trends of radioactive materials in the environment at and adjacent to nuclear facilities and waste disposal sites.

Specifically, NFM is developed to:

- Monitor all inactive, existing, and new LLW disposal sites to assess both radiological and nonradiological hazards (DOE Order 5820.2A)

- Determine the effectiveness of effluent treatment and controls in reducing effluents and emissions (DOE/EH-0173T)

- Detect and quantify unplanned releases (DOE/EH-0173T, 40 CFR 302, WAC 173-303-145, and DOE Orders 232.1 and 5484.1)

- Monitor fugitive emissions and diffuse sources from contaminated areas for compliance with NESHAP (40 CFR 61), DOE/EH-0173T, Toxic Air Emissions Inventory (40 CFR 265, Subparts AA \& B13), State Operating Permit Program (40 CFR 70), and Source Registration (WAC 246-247)

- Monitor all surplus facilities before decontaminating or decommissioning (DOE Order 5820.2A)

- Monitor new and existing sites, processes, and facilities for potential impacts and releases (DOE Order 5484.1 and DOE/EH-0173T)

- Monitor and assess radioactive contamination and potential exposure to personnel and the public (DOE Orders 5400.1 and 5400.5). 
The purpose and justification for NFM includes the following.

- NFM provides a level of assurance to FH that the effluent and contamination controls for the various facilities and waste sites are effective.

- A secondary aspect of NFM is additional assurance beyond that provided by the Occupational Health and Safety Program that it is safe to work onsite and for visitors to safely tour the site.

\subsection{BASIS}

NFM is conducted to (1) monitor personnel protection; (2) monitor environmental protection; and (3) ensure compliance with federal, state, and local regulations.

\subsection{MEDIA SAMPLED AND ANALYSES PERFORMED}

Media include ambient air, surface water, groundwater, external radiation dose, soil, sediment, vegetation, and animals at or near active and inactive facilities and/or waste sites. Parameters monitored include the following, as needed: $\mathrm{pH}$, water temperature, radionuclides, radiation exposure, and hazardous constituents. Animals that are not contaminated, as determined by a field instrument survey, are released to a nonhazardous environment.

\subsection{LOCATIONS}

Samples are collected from known or suspected effluent pathways (e.g., downwind of potential releases, liquid streams, or proximal to release points). To avoid duplication, PNNL established sample sites are used (e.g., air samplers in the 300 Area). There are approximately (numbers and locations could vary from year to year) 60 air samplers, 300 external radiation monitor points (survey points and thermoluminescent dosimeter), 160 soil sample sites, and 95 vegetation sample sites. Animal samples are collected at or near facilities and/or waste sites.

Surveys to detect surface radiological contamination are conducted near and on liquid waste disposal sites (e.g., cribs, trenches, drains, retention basin perimeters, pond perimeters, and ditch banks), solid waste disposal sites (e.g., burial grounds and trenches), unplanned release sites, tank farm perimeters, stabilized waste disposal sites, roads, and firebreaks in the operations areas.

\subsection{PROGRAM REVIEW}

NFM is reviewed at least annually to determine that the appropriate effluents are being monitored and that the monitor locations are in position to best determine potential releases.

\subsection{SAMPLER DESIGN}

Sampler design (e.g., air monitors) will be reviewed at least biannually to determine equipment efficiency and compliance with current EPA and industry [e.g., ANSI and American Society for Testing and Materials (ASTM)] standards. 


\subsection{COMMUNICATION}

FH and PNNL compare and communicate results of their respective monitoring programs at least quarterly and as soon as possible under upset conditions.

\subsection{REPORTS}

Results of NFM are published in annual reports, such as HNF-EP-0527, HNF-EP-0573, and

DOE/RL-99-41. The radionuclide values in these reports are expressed in curies, for each radionuclide per unit weight of sample (e.g., picocuries per gram) or in field instrument values (e.g., counts per minute). Values are reported in this manner, rather than EDE, which is calculated as the summation of the products of the dose equivalent received by specified tissues of the body and a tissue-specific weighting factor. 
HNF-EP-0885 Rev. 1

This page intentionally left blank. 


\subsection{QUALITY ASSURANCE}

The QAPjP (HNF-EP-0528) describes the QA requirements associated with NESHAP compliance. The QAPjP is consistent with the requirements in DOE Order 5700.6C, NQA-1, and EPA QA/R-5. In addition, QA requirements in 40 CFR 60, Appendix B, Method 114, will be considered when performing monitoring calculations and establishing monitoring systems for airborne emissions.

\subsection{OBJECTIVE}

The objective of this plan is to provide a documented QA plan describing QA requirements for implementing the FEMP at WRAP.

\subsection{REQUIREMENTS}

A QAPjP (HNF-EP-0528) has been developed to implement the overall QA program requirements for radioactive airborne emissions data collection and reporting activities. The QAPjP applies specifically to the field activities, laboratory analyses, and continuous monitoring performed for FEMPs. 


\section{HNF-EP-0885 Rev. 1}

This page intentionally left blank. 
HNF-EP-0885 Rev. 1

\subsection{INTERNAL AND EXTERNAL PLAN REVIEW}

DOE Order 5400.1, Chapter IV.4, requires that the FEMP be reviewed annually and updated every 3 years. The FEMP should be reviewed and updated as necessary after each major change or modification in the facility processes, facility structure, ventilation and liquid collection systems, monitoring equipment, waste treatment, or a significant change to the safety analysis reports. In addition, EPA regulations require that records on the results of radioactive airborne emissions monitoring be maintained onsite for 5 years. Operations management maintains records of measurements of stack particulates or other nonradioactive hazardous pollutant emissions for 3 years.

An annual effluent discharges reports for each area on the Hanford Site are prepared to cover both airborne and liquid release pathways. In addition, a report on the air emissions and compliance to the Federal Clean Air Act of 1977 is prepared and submitted to the EPA as well as DOE Headquarters.

Contractor management is responsible for assigning appropriate personnel to perform the reviews, assessments, and approvals as required, and for maintaining this documentation. DOE-RL could require additional review, as necessary, to ensure program integrity. 
HNF-EP-0885 Rev. 1

This page intentionally left blank. 


\subsection{COMPLIANCE ASSESSMENT}

The following section provides a detailed comparison of the effluent monitoring system described in Section 7.0 with the applicable regulations presented in Section 3.0. Based on the information presented previously, the WRAP gaseous effluent stream is not out of compliance with the requirement to provide monitoring. Furthermore, all radioactive and nonradioactive hazardous materials that potentially are released through this steam will be monitored as required. This section also verifies compliance and applicability of federal, state, and local effluent regulations and DOE Orders for WRAP monitoring.

The estimated potential hazardous material inventory quantities are not expected to exceed their respective CERCLA RQ values on a 24 -hour basis. Therefore, no federal, state, and local effluent regulations as well as DOE Orders require any special regulated material monitoring requirements for WRAP. However, the potential EDE for airborne emissions radioactive constituents does exceed the limit listed in 40 CFR 61, Subpart H, NESHAPs. Therefore, full compliance is required.

All of the monitoring and sampling equipment is designed in accordance and compliance with all applicable federal, state, and local laws and standards.

All of the monitoring instrument specifications are designed to comply fully with the monitoring criteria outlined in federal, state, and local laws and regulations found in Section 3.0.

The gaseous effluent discharge ranges developed in Section 5.0 fall well within the ranges of the monitoring and sampling instrumentation specifications. 
HNF-EP-0885 Rev. 1

This page intentionally left blank. 


\subsection{SUMMARY AND CONCLUSIONS}

This FEMP assesses the magnitude of routine and potential liquid and airborne effluent releases from WRAP to determine the compliance of effluent monitoring systems and sampling programs with applicable federal, state, and local regulations. Based on the data reviewed, the gaseous effluents from the main discharge stack were determined to require a monitoring plan according to applicable regulations identified in Section 3.0. The compliance of the monitoring and sampling system for the category A effluent stream is documented in this plan. The two miscellaneous discharge streams were determined to not require a monitoring plan because of the extremely limited quantities of regulated constituents that potentially could enter the stream. This also is documented in the monitoring plan and the facility effluent monitoring plan determination. 
HNF-EP-0885 Rev. 1

This page intentionally left blank. 
HNF-EP-0885 Rev. 1

\subsection{REFERENCES}

ANSI N13. Guide to Sampling Airborne Radioactive Materials in Nuclear Facilities 1, American National Standards Institute, 1969 New York, New York.

ANSI N42.18 Specification and Performance of Onsite Instrumentation for Continuously Monitoring Radioactivity in Effluents, 1974 , American National Standards Institute, New York, New York.

Benton Clean Air Authority, Regulation 1, Kennewick, Washington.

DOE Order 232.1, Occurrence Reporting and Processing of Operations Improvements

DOE Order 5000.3b, Occurrence Reporting and Processing of Operations Information

DOE Order 5400.1, General Environmental Protection Program

DOE Order 5400.5, Radiation Protection of the Public and the Environment

DOE Order 5484.1, Environmental Protection, Safety, and Health Protection Information Reporting Requirements

DOE Order 5700.6C, Quality Assurance

DOE Order 5820.2A, Radioactive Waste Management

DOE/EP-0096, A Guide for Effluent Radiological Measurements at DOE Installations as amended

DOE/EH-0173T, Environmental Regulatory Guide for Radiological Effluent Monitoring and Environmental Surveillance, 1991

DOE/RL-91-50, Rev. 2, Environmental Monitoring Plan

DOE/RL-93-18, Plan and Schedule for Disposition and Regulatory Compliance for Miscellaneous Streams, as amended

DOE/RL-95-85, Inventory of Miscellaneous Stream

DOE/RL-99-41, Radionuclide Air Emissions Report for the Hanford Site, Calendar Year 1998

EPA, Authorization to Discharge Under the National Pollutants Discharge Elimination System, NPDES, Permit WA-000374-3, 1981, U.S. Environmental Protection Agency, Washington, D.C.

HNF-EP-0063, Hanford Site Solid Waste Acceptance Criteria.

HNF-EP-0527, Environmental Releases for Calendar Year 1998,.

HNF-EP-0528-3, NESHAP Quality Assurance Project Plan for Radioactive Airborne Emissions

HNF-EP-0835-5, Statement of Work for Services Provided by the Waste Sampling and Characterization Facility for the Effluent and Environmental Program during Calendar Year 1999. 
HNF-EP-0885 Rev. 1

HNF-PRO-450, Air Quality-Radioactive Emissions Program

HNF-PRO-453, Spill and Release Reporting

HNF-PRO-456, Water Quality Program

HNF-PRO-1929, Requirements Management

HNF-PRO-2364, Radioactive Airborne Effluent Sampling

HNF-SD-CP-QAPP-017, Rev. 3, Waste Sampling and Characterization Facility Quality Assurance Program Plan

SW-846, Test Methods for evaluating Solid Waste: Physical/Chemical Methods, as amended, U.S. Environmental Protection Agency, Washington, D.C.

WHC-EP-0438-1, A Guide Preparing Hanford Site Facility Effluent Monitoring Plans, current revision.

WHC-EP-0446-2, Quality Assurance Project Plan for the Facility Effluent Monitoring Plan Activities. 


\section{DISTRIBUTION}

\section{U.S. Department of Energy, Richland Operations Office}

R. M. Gordon

A6-39

R. F. Guercia

S7-55

P. J. Krupin

A2-15

D. C. Ward

A2-15

Public Reading Room

$\mathrm{H} 2-53$

Fluor Hanford

H. C. Boynton (5)

T4-52

W. E. Davis (5)

G1-29

L. P. Diediker

G1-29

T. P. Frazier

G1-29

J. E. Geary

T4-51

M. F. Hackworth

T4-51

D. G. Ranade

G1-27

L. W. Roberts

T4-51

W. R. Thackaberry

T4-52

J. R. Weidert

T4-52

N. P. Willis

T4-52

SWDPC-1

Pacific Northwest National Laboratory

E. G. Damberg

P7-68

A. K. Ikẹnberry

P7-79

R. K. Woodruff

K6-13

Hanford Technical Library

P8-55

Lockheed Martin Services, Inc.

Central Files

B1-07

DPC

H6-08 
HNF-EP-0885 Rev. 1

This page intentionally left blank. 